NBER WORKING PAPER SERIES

\title{
INFLATION TARGETING IN EMERGING MARKET ECONOMIES
}

\author{
Arminio Fraga \\ Ilan Goldfajn \\ André Minella \\ Working Paper 10019 \\ http://www.nber.org/papers/w10019
}

\author{
NATIONAL BUREAU OF ECONOMIC RESEARCH \\ 1050 Massachusetts Avenue \\ Cambridge, MA 02138 \\ October 2003
}

We thank the participants in the NBER Eighteenth Annual Conference on Macroeconomics, especially Mark Gertler, Robert Hall, Frederic Mishkin, and Kenneth Rogoff, and seminar participants at Princeton University for their comments. We are also grateful to Fabia A. de Carvalho, Eduardo Loyo and Marcio I. Nakane for their suggestions, to Thaís P. Ferreira and Myrian B. S. Petrassi for research assistance, and to Marcileide A. da Silva and Raquel K. de S. Tsukada for assistance with data. The views expressed are those of the authors and not necessarily those of the Central Bank of Brazil. The views expressed herein are those of the authors and are not necessarily those of the National Bureau of Economic Research.

C2003 by Arminio Fraga, Ilan Goldfajn, and André Minella. All rights reserved. Short sections of text, not to exceed two paragraphs, may be quoted without explicit permission provided that full credit, including (C) notice, is given to the source. 
Inflation Targeting in Emerging Market Economies

Arminio Fraga, Ilan Goldfajn, and André Minella

NBER Working Paper No. 10019

October 2003

JEL No. E31, E52, E58

\section{$\underline{\text { ABSTRACT }}$}

This paper assesses inflation targeting in emerging market economies (EMEs), and develops applied prescriptions for the conduct of monetary policy and inflation-targeting design in EMEs. We verify that EMEs have faced more acute trade-offs - higher output and inflation volatility - and worse performance than developed economies. These results stem from more pronounced external shocks, lower credibility, and lower level of development of institutions in these countries. In order to improve their performance, we recommend high levels of transparency and communication with the public and the development of more stable institutions. At an operational level, we propose a procedure that a central bank under inflation targeting can apply and communicate when facing strong supply shocks, and suggest a monitoring structure for an inflation-targeting regime under an IMF program.

Arminio Fraga

Partner, Gavea Investimentos

Rua Dias Ferreira, 190

22431-050 - Rio de Janeiro - RJ

Brazil

Ilan Goldfajn

Department of Economics

Pontifical Catholic University of Rio de Janeiro (PUC-Rio)

Marques de São Vicente, 225

22453-900 - Rio de Janeiro - RJ

Brazil

goldfajn@econ.puc-rio.br
André Minella

Research Department

Central Bank of Brazil

SBS - Quadra 3 - Bloco B - Edifício-Sede - 9ํㅜㅇ andar

70074-900 - Brasília - DF

Brazil

andre.minella@bcb.gov.br 


\section{Introduction}

The performance of inflation targeting regimes around the world has been positive. Average inflation in both emerging markets and developed economies is substantially lower after the adoption of the inflation targeting regime than immediately before its adoption (Figure 1). ${ }^{1}$ However, emerging market economies (EMEs) have had a relatively worse performance. In these countries, deviations from both central targets and upper bounds are larger and more common. ${ }^{2}$

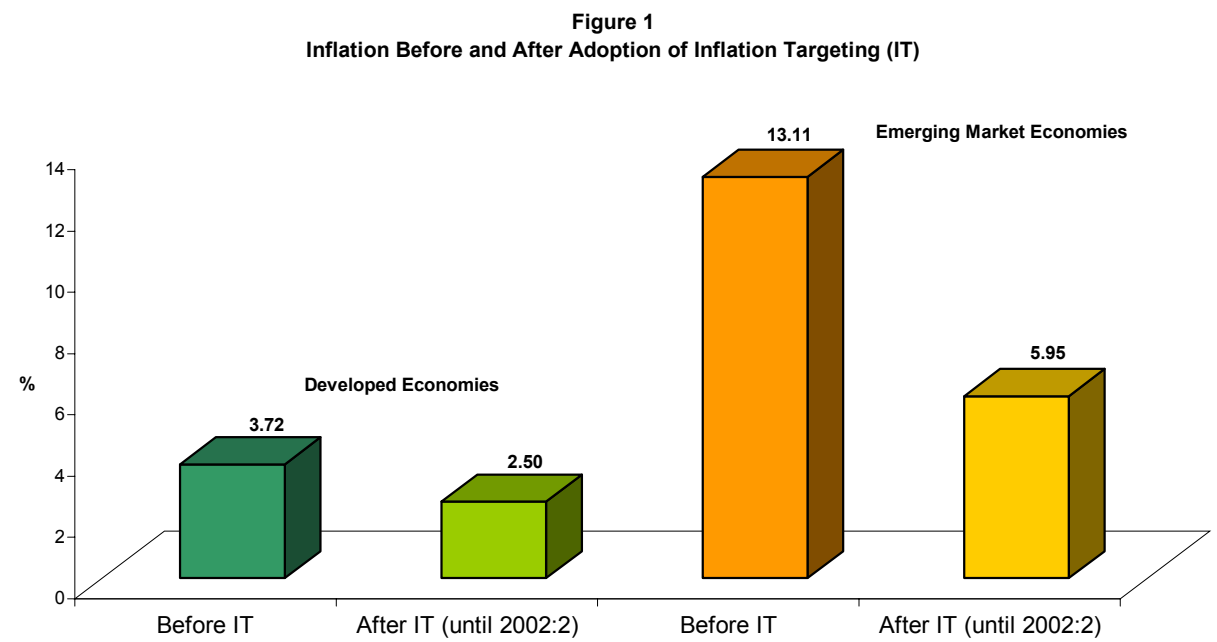

This suggests that either inflation targeters in EMEs are less committed to their targets or inflation targeting in these countries is a more challenging task than in developed ones. The latter explanation is related to the more volatile macroeconomic environment and to weaker institutions and credibility in these countries that lead to more acute trade-offs than the existing ones in developed economies.

\footnotetext{
${ }^{1}$ Bernanke, Laubach, Mishkin, and Posen (1999), Mishkin and Schmidt-Hebbel (2002), and Corbo, Landerretche, and Schmidt-Hebbel (2002) have found evidence of additional gains stemming from inflation targeting. Ball and Sheridan (2003) have found no evidence that inflation targeting countries have had a better performance in the OECD.

${ }^{2}$ The deviations of inflation from central targets and from upper bounds of targets were $81 \%$ and $167 \%$ higher than in developed economies, respectively (table available upon request).
} 
EMEs under inflation targeting have the challenge of breaking the vicious circle between, on one side, low credibility and more fragile institutions, and, on the other side, higher macroeconomic instability and vulnerability to external shocks. It is a long process that involves acquiring credibility as a monetary policy institution committed to price stability in the context of higher instability.

This paper assesses inflation targeting in EMEs, when compared to that in developed economies, and develops applied prescriptions for the conduct of monetary policy and inflation-targeting design. We verify that EMEs have faced more acute tradeoffs than developed countries: both output and inflation are more volatile, and the inflation level is higher. The explanation for the different performance of EMEs relies on the presence of more fragile institutions and imperfect credibility, and on the nature and magnitude of the shocks that hit these economies.

There are several instances where these more acute trade-offs emerge. Take the case of a "sudden stop" in the inflow of capital to an EME leading to a substantial depreciation of the currency (e.g. Brazil in 2002 was faced with a negative swing of USD 30 billion - or $6 \%$ of GDP - in capital flows relative to an already difficult 2001 that led to a nominal depreciation of $50 \%$ ). Even in a context of good initial conditions - low pass-through and 12-month forward inflation expectations on track - this event led to a breach of the inflation target and, given some inertia, to a worsening of both inflation expectations and actual future inflation (Brazil's target of $4 \%$ was breached with an inflation of $12.5 \%$, and 12-month forward inflation expectations were $11.0 \%$ at the end of December 2002). In this context, what is the optimal response to these types of shocks? Should one take 24 months or longer to converge to the target even when building credibility and reputation is still important? 
In general, in the more volatile environment in EMEs, some applied and theoretical issues deserve attention: i) how to build credibility when faced with larger shocks? How to balance flexibility and credibility in such instance? ii) how does an inflation targeting regime work in a disinflation process? And in a credibility building process? iii) how to deal with shocks that represent important changes in relative prices? iv) should bands be wider and the central points of inflation targets be higher in EMEs? v) how should IMF conditionality be designed with an inflation targeting country?

The paper discusses these monetary policy issues. Its focus, therefore, is more applied. For that purpose, our analysis is based on empirical findings for EMEs and, in particular, on our own experience at the Central Bank of Brazil, besides the use of simulations of a model to guide our discussions. In a way, as the case of Brazil represents the first stress test of an inflation targeting regime, the lessons learned may someday be useful for other countries.

We stress the role of communication and transparency as crucial for the process of building credibility. Once the main issues are laid out, as a by-product, the paper also includes two applied proposals. The first is a transparent procedure that a central bank under inflation targeting can apply and communicate when facing strong supply shocks. The second is a design of a monitoring structure for an inflation-targeting regime under an IMF program.

The paper is organized as follows. The second section presents some stylized facts about EMEs and developed countries. It contains a statistical comparison of the conduct and results of monetary policy in EMEs and developed countries. The third section presents a theoretical model of a small open economy, which is employed to simulate the effects of some shocks and changes in inflation targets. The fourth section discusses some explanations for why EMEs face higher volatility. It analyzes the 
challenge of constructing credibility and reducing inflation levels, the effect of large external shocks, and addresses issues on fiscal and financial dominance. Section five addresses how to deal with shocks.

\section{Stylized facts about inflation targeting in emerging market economies}

In this section we present basic stylized facts comparing the volatilities of inflation, output, exchange rates, and interest rates, and average of inflation and output growth in emerging markets and developed economies. ${ }^{3}$

We have faced two difficulties in defining the differences across the two country groups. First, there exist some differences across EMEs; therefore, not all characteristics that we list are common to all these economies. However, given that they are present in a significant part of the group, we call them "stylized facts". Second, in most EMEs, the adoption of inflation targeting is recent, making it difficult to draw conclusions and to apply econometric methods. Table 1 shows the dates of adoption for emerging and developed economies. The number of inflation targeters among developing and developed economies amounts to 12 and 8, respectively. Most of the developed countries adopted inflation targeting between 1990 and 1993, whereas the majority of the developing countries adopted it from 1998 on.

\footnotetext{
${ }^{3}$ The assessment of some country experiences and of some issues involved in the design of the inflation targeting can be found in Bernanke, Laubach, Mishkin, and Posen (1999), Truman (2002), Mishkin and Schmidt-Hebbel (2002), Schmidt-Hebbel and Werner (2002), Corbo and Schmidt-Hebbel (2001), and Minella, Freitas, Goldfajn, and Muinhos (2002).
} 
Table 1

Initial Targets and Inflation Around Adoption of Inflation Targeting

(12-Month Accumulated Inflation)

\begin{tabular}{|c|c|c|c|c|}
\hline & $\begin{array}{l}\text { Date of Adoption } \\
\text { Inflation Targeting }\end{array}$ & First Target & $\begin{array}{c}\text { Inflation Right } \\
\text { Before IT Adoption }\end{array}$ & $\begin{array}{l}\text { Inflation } 12 \\
\text { Months After IT } \\
\text { adoption }\end{array}$ \\
\hline \multicolumn{5}{|c|}{ Developed Economies } \\
\hline Australia & Apr-93 & $2 \%-3 \%$ & 1.22 & 1.74 \\
\hline Canada & Feb-91 & $3 \%-5 \%$ & 6.83 & 1.68 \\
\hline Iceland & Mar-01 & $2.5 \%(-1.5 \%+3.5 \%)$ & 4.05 & 8.72 \\
\hline New Zealand & Mar-90 & $3 \%-5 \%$ & 7.03 & 4.52 \\
\hline Norway & Mar-01 & 2.5 & 3.64 & 1.10 \\
\hline Sweden & Jan-93 & $2 \%(+-1 \%)$ & 1.76 & 1.70 \\
\hline Switzerland & Jan-00 & $<=2 \%$ & 1.63 & 0.90 \\
\hline United Kingdom & Oct-92 & $1 \%-4 \%$ & 3.57 & 1.35 \\
\hline Average & & 2.8 & 3.72 & 2.71 \\
\hline Median & & 2.5 & 3.61 & 1.69 \\
\hline \multicolumn{5}{|c|}{ Emerging Market Economies } \\
\hline Brazil* $^{*}$ & Jun-99 & $8 \%(+-2 \%)$ & 3.15 & 6.51 \\
\hline Chile & Jan-91 & $15 \%-20 \%$ & 27.31 & 19.47 \\
\hline Colombia & Sep-99 & $15 \%$ & 9.22 & 9.35 \\
\hline Czech Republic & Jan-98 & $5.5 \%-6.5 \%$ & 9.98 & 3.5 \\
\hline Hungary & Jun-01 & $7 \%(+-1 \%)$ & 10.78 & 4.87 \\
\hline Israel & Jan-92 & $14 \%-15 \%$ & 18.03 & 10.74 \\
\hline Mexico & Jan-99 & $<=13 \%$ & 18.61 & 11.03 \\
\hline Peru & Jan-94 & $15 \%-20 \%$ & 39.49 & 13.71 \\
\hline Poland & Oct-98 & $<=9.5$ & 10.44 & 8.82 \\
\hline South Africa** & Feb-00 & $3 \%-6 \%$ & 2.65 & 7.77 \\
\hline South Korea & Jan-98 & $9 \%(+-1 \%)$ & 6.57 & 1.46 \\
\hline Thailand & Apr-00 & $0 \%-3.5 \%$ & 1.04 & 2.47 \\
\hline Average & & 10.3 & 13.11 & 8.31 \\
\hline Median & & 9.3 & 10.21 & 8.30 \\
\hline
\end{tabular}

* In Brazil, the inflation of the period previous to the adoption of inflation targeting was in part a result of the overappreciation of the domestic currency.

${ }^{* *}$ First target established for 2002.

We consider two samples. The first refers to the period after the adoption of inflation targeting in each country. The objective is to compare countries with the same regime. However, since the periods across countries are different, the world macroeconomic environment is different as well. Then we consider a second sample that refers to a recent period, which includes Asian, Brazilian and Russian crises: 1997mid-2002, which we refer to as fixed sample. In this case, some countries are inflation 
targeters in the whole sample, whereas others are just in part of it. Table 2 and Figure 2 record the data for the second sample. ${ }^{4}$

Table 2

Volatility and Average of Selected Variables for 1997:1 - 2002:2

\begin{tabular}{|c|c|c|c|c|c|c|}
\hline \multirow{2}{*}{ Countries } & \multicolumn{4}{|c|}{ Volatility of Basic Variables } & \multicolumn{2}{|c|}{ Average } \\
\hline & Inflation & $\begin{array}{c}\text { Exchange } \\
\text { Rate* }^{*}\end{array}$ & $\begin{array}{c}\text { GDP } \\
\text { Growth** }\end{array}$ & Interest Rate & $\begin{array}{l}\text { GDP } \\
\text { Growth }\end{array}$ & Inflation \\
\hline \multicolumn{7}{|l|}{ Developed Economies } \\
\hline Australia & 2.05 & 0.13 & 1.96 & 0.58 & 4.78 & 5.89 \\
\hline Canada & 0.83 & 0.04 & 1.30 & 1.14 & 3.57 & 1.96 \\
\hline Iceland & 2.45 & 0.15 & 3.13 & 3.02 & 4.17 & 4.05 \\
\hline New Zealand & 1.21 & 0.16 & 3.61 & 1.47 & 3.09 & 1.65 \\
\hline Norway & 0.77 & 0.10 & 2.25 & 1.46 & 2.66 & 2.44 \\
\hline Sweden & 1.11 & 0.12 & 2.41 & 0.44 & 2.58 & 1.24 \\
\hline Switzerland & 0.54 & 0.08 & 1.14 & 0.92 & 1.79 & 0.85 \\
\hline United Kingdom & 0.92 & 0.06 & 0.79 & 1.13 & 2.61 & 2.46 \\
\hline Average & 1.24 & 0.11 & 2.07 & 1.27 & 3.16 & 2.57 \\
\hline Median & 1.02 & 0.11 & 2.11 & 1.13 & 2.88 & 2.20 \\
\hline \multicolumn{7}{|c|}{ Emerging Market Economies } \\
\hline Brazil & 2.09 & $0.15^{\star \star \star}$ & 2.06 & 7.06 & 1.81 & 5.89 \\
\hline Chile & 1.30 & 0.17 & 3.25 & - & 3.11 & 3.88 \\
\hline Colombia & 5.43 & 0.25 & 3.38 & 10.02 & 0.81 & 12.51 \\
\hline Czech Republic & 3.46 & 0.09 & 2.73 & 5.81 & 1.18 & 5.31 \\
\hline Hungary & 4.09 & 0.16 & - & 1.13 & - & 11.21 \\
\hline Israel & 3.18 & 0.10 & 3.36 & 3.34 & 2.98 & 4.35 \\
\hline Mexico & 5.98 & 0.07 & 3.17 & 7.26 & 4.05 & 11.72 \\
\hline Peru & 3.04 & 0.11 & 3.45 & 5.50 & 2.11 & 3.89 \\
\hline Poland & 4.13 & 0.11 & 2.40 & 4.14 & 3.85 & 8.40 \\
\hline South Africa & 2.13 & 0.26 & 1.11 & 3.65 & 2.26 & 6.51 \\
\hline South Korea & 2.36 & 0.14 & 6.38 & 5.52 & 4.31 & 3.73 \\
\hline Thailand & 3.25 & 0.14 & 6.13 & 6.72 & 0.08 & 2.88 \\
\hline Average & 3.37 & 0.15 & 3.40 & 5.47 & 2.41 & 6.69 \\
\hline Median & 3.22 & 0.14 & 3.25 & 5.52 & 2.26 & 5.60 \\
\hline
\end{tabular}

Data source: International Financial Statistics, IMF (quarterly data).

${ }^{*}$ refers to the coefficient of variation (standard deviation/average).

** growth rate measured comparing the current quarter to the quarter of the previous year.

*** refers to the period 1999:1-2002:2. For 1997:1-2002:2, the value is 0.31 .

In both samples, the date indicate that, in comparison to developed economies, the volatilities of all variables-inflation, exchange rate, ${ }^{5}$ output and interest rate-and the inflation level are higher in EMEs. The more challenging trade-off faced by EMEs is

\footnotetext{
${ }^{4}$ The data referring to the first sample is available upon request.

${ }^{5}$ For the inflation targeting sample, the measured exchange rate volatility is similar.
} 
illustrated in Figure 3, which shows the combination of variability of output growth and inflation for each country for 1997:1-2002:2.

Figure 2

Volatilities of Selected Variables of the period 1997-2002 (Average of Standard Deviation)

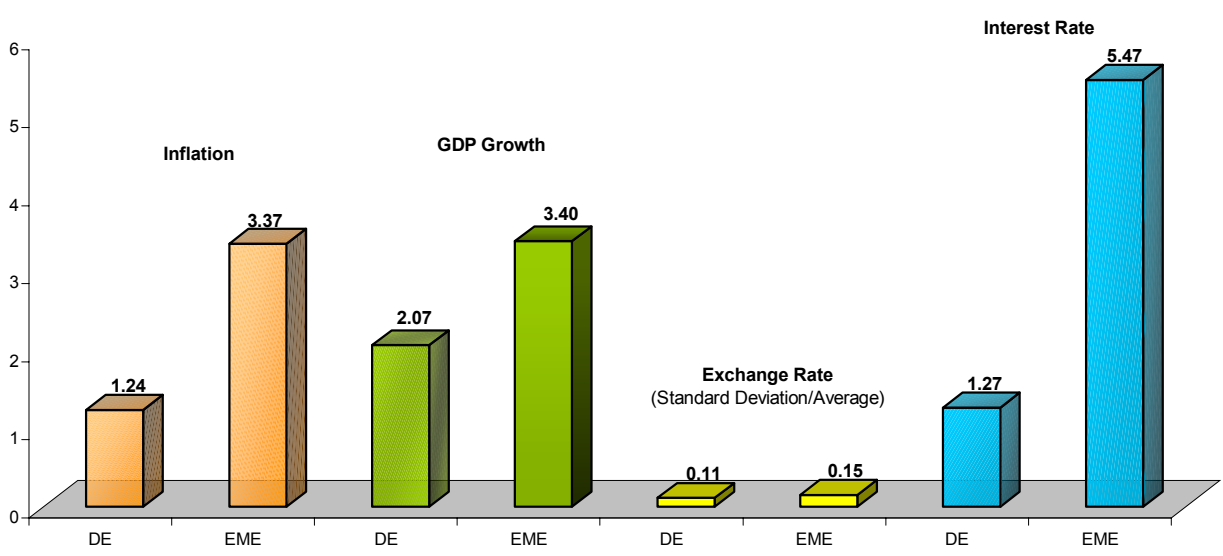

Figure 3

Trade-off Volatilities Output and Inflation (1997:1 - 2002:2)

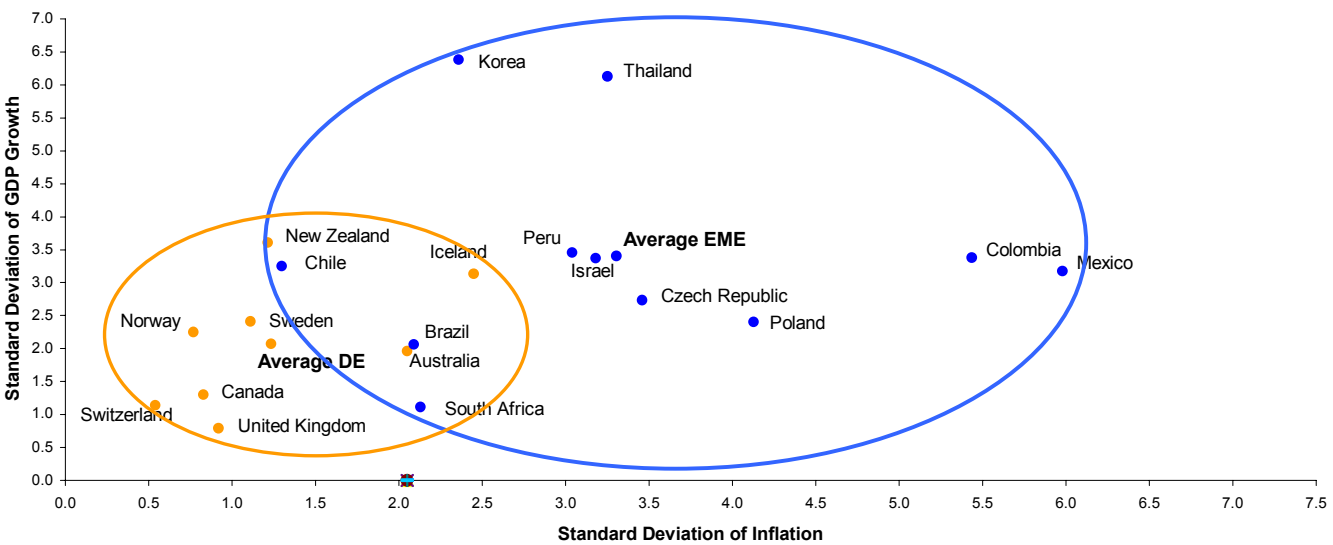




\section{Model}

We develop a small open economy model in order to illustrate the main points raised in the paper. The objective is to simulate the effects of some shocks and changes in inflation targets. The model combines features of Batini, Harrison, and Millard's (2001), and McCallum and Nelson's (2000) formulations.

Imports enter as intermediate goods in contrast to large part of open economy literature, which usually uses a model with imports as consumption goods. As stressed by McCallum and Nelson (2000), a specification where imports enter as intermediate goods captures better the features of data. In comparison to models where imports enter as consumption goods, such as in Galí and Monacelli (2002), McCallum and Nelson's (2000) model generates a lower and more delayed correlation between exchange rate changes and inflation rate, closer to that observed in the data. Furthermore, intermediate goods are the major item in imports. Table 3 records the share in imports of goods classified by use for five countries. On average, consumption goods represent only $21.3 \%$ of the total imports, whereas capital and intermediate goods shares are $29.5 \%$ and $46.2 \%$, respectively. Since there is no imported consumption goods in the model, there is no distinction between domestic and CPI inflation, differently from Svensson (2000) and Galí and Monacelli (2002).

Table 3

Imports Classified by Use - 2001

\begin{tabular}{lrrrr}
\hline \multicolumn{1}{c}{ Countries } & Consumption & Capital & $\begin{array}{c}\text { Intermediate } \\
\text { (including fuel) }\end{array}$ & Total \\
\hline Australia & $30.2 \%$ & $21.3 \%$ & $48.5 \%$ & $100.0 \%$ \\
Brazil & $12.8 \%$ & $26.6 \%$ & $60.6 \%$ & $100.0 \%$ \\
Chile & $19.8 \%$ & $21.0 \%$ & $59.3 \%$ & $100.0 \%$ \\
Mexico & $19.8 \%$ & $57.7 \%$ & $22.5 \%$ & $100.0 \%$ \\
New Zealand* & $24 \%$ & $21 \%$ & $40 \%$ & $85 \%$ \\
Simple Average & $21.3 \%$ & $29.5 \%$ & $46.2 \%$ & \\
\hline
\end{tabular}

* 1999. Part of imports not classified by use.

Data source: Central banks and national institutes of statistics. 
The model is derived from the optimization of infinitely-lived households and firms. We present directly the log approximation of the variables around the nonstochastic flexible-price steady state. Lower case variables represent log-deviations from their steady-state values. ${ }^{6}$ We present here only the most important equations of the model. ${ }^{7}$ The economy is comprised of households, firms (owned by the households), and government. Firms produce differentiated consumption goods using a CobbDouglas production function:

$$
y_{t}=a_{t}+\alpha n_{t}+(1-\alpha) m_{t}
$$

where $y_{t}$ is output, $a_{t}$ represents a stochastic productivity factor, $n_{t}$ is (domestic) labor, and $m_{t}$ is imported goods.

Production is either consumed by domestic households or exported (therefore, the economy exports consumption goods and imports intermediate ones):

$$
y_{t}=s_{c} c_{t}+s_{x} x_{t}
$$

where $c_{t}$ is domestic consumption, $x_{t}$ is exports, $s_{c}=\left(1-X^{S S} / Y^{S S}\right)$, and $s_{x}=X^{S S} / Y^{S S}$.

The aggregate demand equations are

$$
\begin{aligned}
& c_{t}=E_{t} c_{t+1}-\frac{1}{\gamma_{c}}\left(i_{t}-E_{t} \pi_{t+1}\right)+\varepsilon_{c t}, \\
& x_{t}=\eta q_{t}+y_{t}^{*},
\end{aligned}
$$

\footnotetext{
${ }^{6} x_{t}=\log \left(X_{t}\right)-\log \left(X_{t}^{S S}\right)$, where $\mathrm{X}_{\mathrm{t}}^{\mathrm{SS}}$ is the steady-state value for $\mathrm{X}_{\mathrm{t}}$, and log is the natural logarithm. Since $\log \left(1+r_{t}\right) \approx r_{t}$, the lower case variables represent percentage deviations from the steady state.

7 The derivation of the model from the optimization of households and firms, and all the equations resulting from the log-linearization are available upon request.
} 
where $i_{t}$ is the nominal interest rate, $E_{t}$ is the expectations operator, inflation is $\pi_{t}=p_{t}-p_{t-1}, \quad p_{t}$ is the price level, $\gamma_{c}$ is the inverse of the intertemporal elasticity of substitution for consumption, $\varepsilon_{c t}$ is a shock to preferences, $\eta$ is the elasticity of substitution between domestic and foreign goods, $q_{t}$ is the real exchange rate defined as $q_{t}=s_{t}+p_{t}^{*}-p_{t}, s_{t}$ is the nominal exchange rate, defined as the price in domestic currency of a unit of foreign currency, $p_{t}^{*}$ is the foreign price level, and $y_{t}^{*}$ is output of the rest of the world. Star ${ }^{*}$ indicates a variable of the rest of the world. All variables of the rest of the world are treated as exogenous in the model.

The model has domestic and foreign bonds, both private. Domestic bonds are denominated in domestic currency and are held only by domestic residents. Foreign bonds are denominated in foreign currency, and their prices include a stochastic country risk premium. The derived uncovered interest rate parity condition is presented below:

$$
i_{t}-i_{t}^{*}=E_{t} s_{t+1}-s_{t}+\zeta_{t}
$$

where $i_{t}^{*}$ is the rest of the world interest rate, and $\zeta_{t}$ is the country risk premium.

Firms maximize the difference between expected marginal revenue and unit cost. There is price rigidity: only a fraction of firms is allowed to adjust prices each period. The choice of the optimum price for the firm yields $\pi_{t}=\beta E_{t} \pi_{t+1}+\lambda v_{t}$, where $\beta$ is a discount factor, and $v_{t}$ is the real unit cost given by: ${ }^{8}$

$$
v_{t}=\alpha w_{t}+(1-\alpha) p_{M t}-a_{t}-p_{t}
$$

\footnotetext{
${ }^{8} \lambda=\frac{(1-\theta)(1-\beta \theta)}{\theta}$, where $\theta$ is the probability of the firm not adjust its price in period $t$.
} 
where $w_{t}$ is wage, and $p_{M t}$ is the price of imports in domestic currency defined as $p_{M t}=s_{t}+p_{M t}^{*}$, where $p_{M t}^{*}$ is the price of imports in foreign currency. Note that inflation is affected by exchange rate via price of intermediate goods.

Nevertheless, this formulation of the Phillips curve delivers some counterfactual results, as stressed in Galí and Gertler (1999) and Fuhrer (1997). It implies that current changes in inflation are negatively related to the lagged output gap, that is, a positive output gap would lead to a reduction in the inflation rate in the following period. In contrast, the empirical evidence is that a positive output gap is followed by an increase in the inflation rate over the cycle. Moreover, this formulation implies that, with perfectly credible announcements, a disinflation is costless.

These empirical results have motivated some authors to work with a hybrid Phillips curve: besides the expected inflation term, the equation also contains a lagged term for inflation. In the paper, we do not have special concern about the specific derivation for the persistence in inflation. ${ }^{9}$ As in Galí and Gertler (1999), one possibility is to consider that there is a fraction of backward-looking firms. ${ }^{10}$

In addition, we can also postulate a "cost-push" shock. This term could reflect changes in the mark-up resulting from movements in price-elasticity of demand over the cycle or in tax rates. It could also be used as a proxy for the case of change in relative prices across sectors. ${ }^{11}$ The resulting aggregate supply equation is:

\footnotetext{
${ }^{9}$ Fuhrer and Moore (1995) have generated inflation persistence assuming that agents care about relative wages over the life of the wage contract. Roberts $(1997,1998)$ has found some empirical evidence that expectations are less than perfectly rational: a fraction of the agents would have adaptive expectations or there would be a partial adjustment of expectations (these would adjust only gradually to the fully rational value). Galí and Gertler (1999) have found that the fraction of backward-looking firms is statistically significant, although not quantitatively important.

${ }^{10}$ For simplification, we are assuming that $\lambda$ is not affected by the presence of the backward-looking term.

${ }^{11}$ For example, in the Brazilian case, there has been an important change in relative prices in the last years, only partially related to exchange rate and international prices movements.
} 


$$
\pi_{t}=\gamma_{f} E_{t} \pi_{t+1}+\lambda v_{t}+\gamma_{b} \pi_{t-1}+\mu_{t}
$$

where $\gamma_{b}+\gamma_{f}=1$.

We assume that the shocks follow stationary univariate autoregressive processes of order one.

The interest rate is the policy instrument. Monetary policy is given by a Taylortype simple rule or by optimal simple rules. In the latter the optimal coefficients are obtained by the minimization of the standard central bank's intertemporal loss function that penalizes deviations of output gap $\left(\tilde{y}_{t}\right)$ and inflation from their targets:

$$
\frac{1}{2} E_{t}\left\{\sum_{i=0}^{\infty} \beta^{i}\left[w_{y}\left(\tilde{y}_{t+i}\right)^{2}+\left(\pi_{t+i}-\pi_{t+i}^{T}\right)^{2}\right]\right\},
$$

where $w_{y}$ is related negatively to the aversion to inflation variability, ${ }^{12} \pi_{t}^{T}$ is the inflation target, and $\tilde{y}_{t}=y_{t}-\bar{y}_{t}$, where $\bar{y}_{t}$ is potential output, which is defined as the output that would prevail in the case of fully price flexibility. The interest rate is restricted to react to selected variables. We use the algorithm in Dennis (2002) to estimate the optimal simple rule. ${ }^{13}$

\footnotetext{
${ }^{12}$ In the simulations, we have considered different values for $w_{y}$. We are not concerned about the derivation of this parameter based on microfoundations. This objective function can be derived from a household utility function in the presence of price rigidity (Rotemberg, and Woodford, 1998; Woodford, 2002). Woodford (2002) has also derived the objective function in the case where prices are indexed to a lagged price index between the occasions on which they are re-optimized. The objective function includes a quasi-differenced inflation rate term rather than the inflation rate itself. We have used the usual objective function based on the following grounds: i) the objective function is used only to have an idea of the optimal coefficients in the central bank's reaction function; ii) in practice, this objective function seems to be more used by central banks.

${ }^{13}$ The explanation of the calibration of the model is available upon request.
} 


\section{Explaining the higher volatility: building credibility, reducing the inflation}

\section{levels, and dealing with fiscal, financial and external dominance}

The conduct of monetary policy in EMEs faces at least three major challenges: i) to build credibility, ii) to reduce the level of inflation, and iii) to deal with fiscal, financial and external dominance. The presence of low credibility, inflation levels superior to the long-term goal, and large shocks result in higher volatility of output, inflation, and interest rate. Fiscal and financial dominance issues also have implications for these variables. In this section, we show how all these elements can help explain the stylized facts presented previously.

The explanation for the different performance of EMEs relies on the presence of more fragile institutions and imperfect credibility, on the necessity of reduction of inflation levels, and on the nature and magnitude of the shocks that hit these economies.

\subsection{Building credibility and reducing inflation rate levels}

Institutions in emerging economies tend to be weaker than in developed economies. Central banks are no exception. In this context, the adoption of inflation targeting represents an effort to enhance the credibility of the monetary authority as committed to price stability.

Nevertheless, building credibility takes time. During this transition period, central bank's actions not only have to be consistent with the inflation targeting framework, but also have to take into account that private agents do not fully trust that central bank will act accordingly. Private agents have concerns about the commitment of the central bank to the target itself, and to its reaction to shocks. In the first case, given the history of low credibility, private agents assign some positive probability that the central bank will renege on its commitment to the targets. As a result, the expected 
inflation and consequently the actual inflation tend to be higher than with a perfectly credible monetary authority. Similarly, when the economy is hit by an inflationary shock, private agents do not trust completely that the central bank will react strongly. As a consequence, the central bank incurs a cost of trust building as it has to react to curb the inflationary pressures stemming from low credibility and has to "prove" that is committed to the new regime. During some period, the volatility of interest rate and output will be higher, and, since the central bank also takes into account output costs, the inflation volatility also tends to be higher when compared to a situation of full credibility.

Imperfect credibility concerning the fulfillment of the targets becomes more important as we consider that the role of inflation targeting in emerging economies is not only to assure that inflation will be around its long-term level, but also make it converge to low levels. In fact, emerging market countries have had to face much higher initial inflation rates than developed countries. Table 1 shows the inflation around the moment of adoption of inflation targeting (right before and after), and the initial targets. When inflation targeting was adopted, the average inflation in the developed countries was $3.7 \%$, whereas in the EMEs was $13.1 \%{ }^{14}$ The values are also shown in Figure 4. Half of the developing economies had a two-digit inflation rate when implementing inflation targeting. In the case of Peru, Chile, Israel and Mexico, the inflation rate was $39.5 \%, 27.3 \%, 18.0 \%$ and $18.6 \%$, respectively.

The differences are even clearer when we consider the first targets that were established (Figure 5). In developed economies, the maximum upper bound for the target was $6 \%$, with an average of $2.8 \%$ for the central target, whereas for developing economies the highest upper bound reached $20 \%$, and the average was $10.3 \%$.

\footnotetext{
${ }^{14}$ The low inflation rate in Brazil that prevailed prior to the adoption of inflation targeting was in part a result of an overvalued exchange rate.
} 
Figure 4

12-Month Inflation Right Before IT Adoption

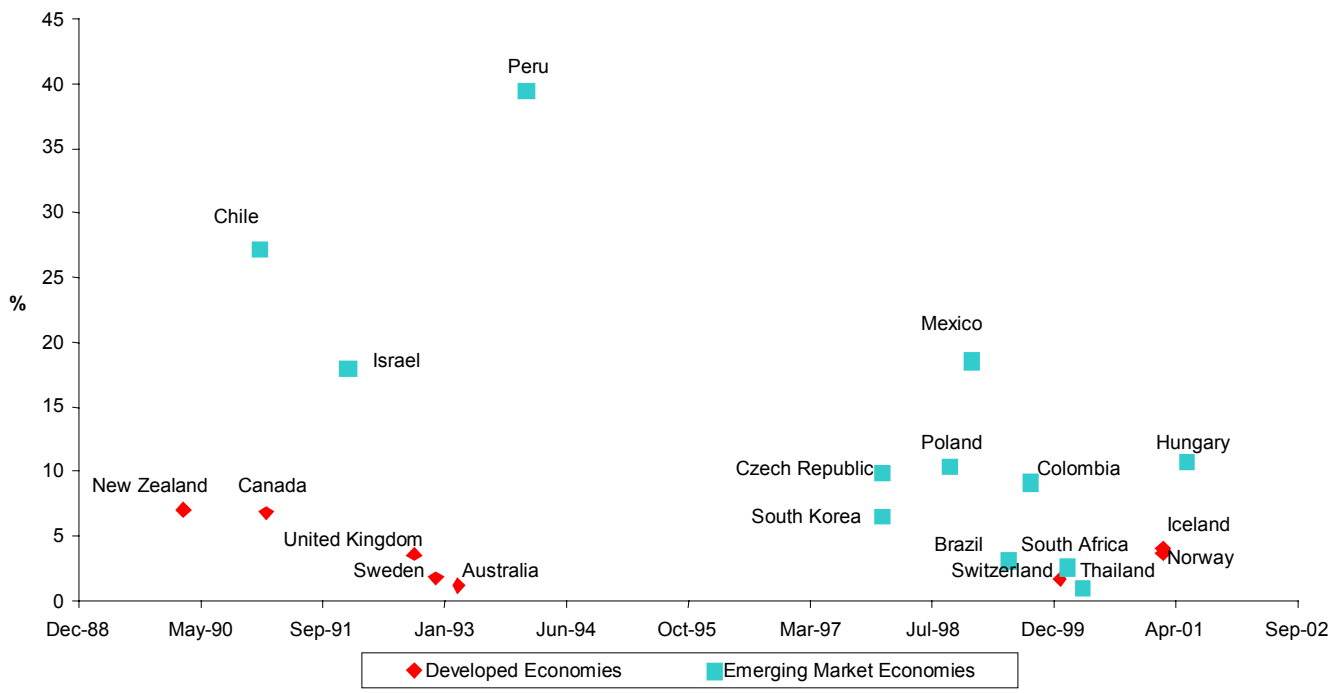

Figure 5

First Central Target Adopted

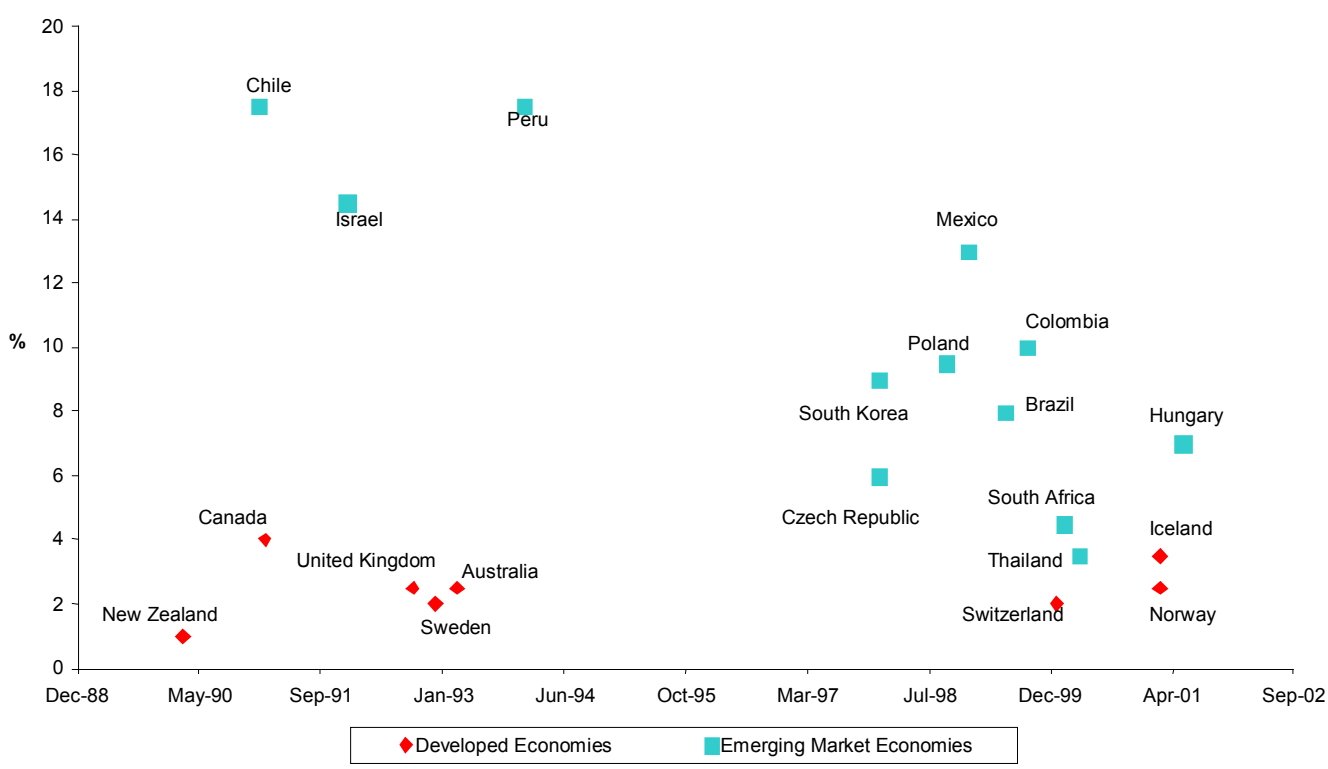

Since inflation was higher than the long-term goal, the targets are decreasing in time. Figure 6 shows the evolution of the central target average for both country groups. They are relatively stable for developed economies, and decreasing for EMEs. 


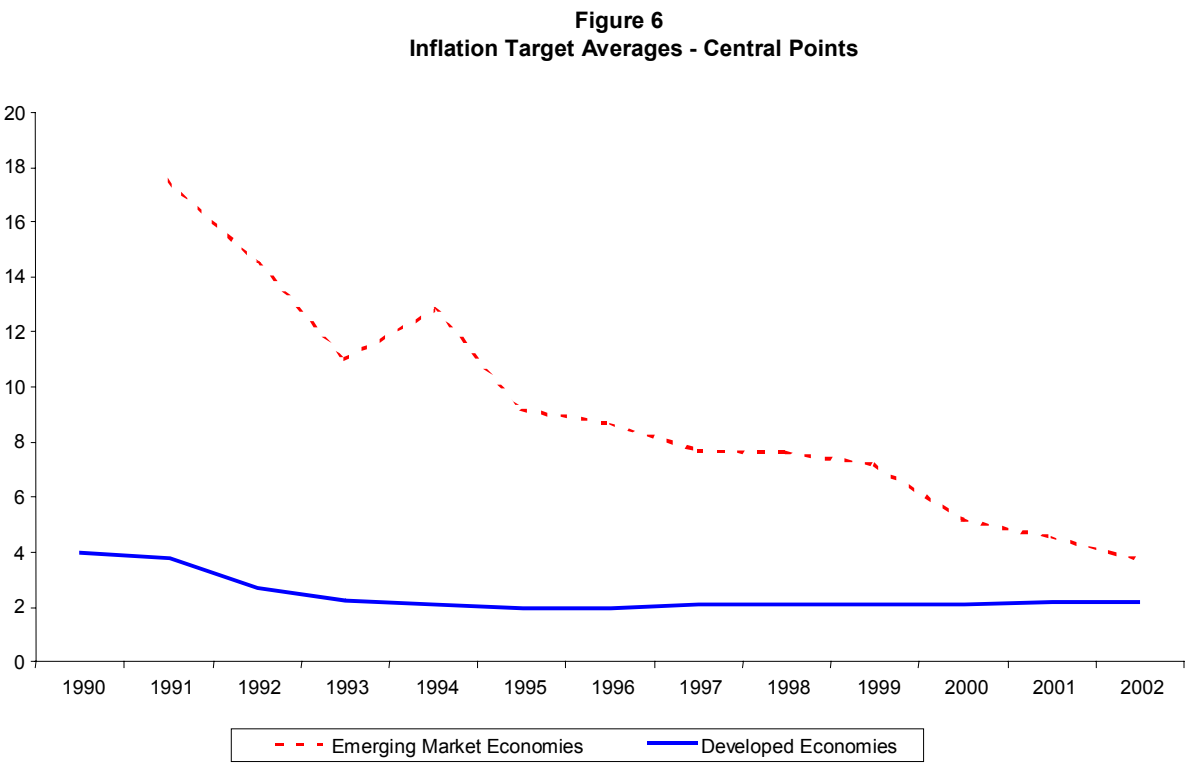

If inflation targeting is adopted in an economy with an inflation rate significantly higher than the long-term goal, the central bank has to conduct an active policy with output costs to bring inflation down. The reduction in inflation faces two obstacles, which result in costly disinflation and higher volatility of inflation and output: (i) the already mentioned imperfect credibility, and (ii) the presence of some degree of inflation persistence, resulting from some backward-looking behavior in price setting. The presence of backward-looking behavior may be due to factors such as indexed wage contracts, and adaptive expectations. In particular, in Brazil, the adjustment of regulated prices such as electricity and telephone service follows a contractual rule that implies a high degree of persistence.

Decreasing targets are a source of possible non-fulfillment of targets because it is difficult to assess the current backward-looking behavior and the speed of future convergence of inflation expectations. The higher deviations from the targets in EMEs may then be related to the variability of shocks as well as to the fact that inflation 
targeting was typically adopted when inflation was significantly higher than the longterm goal.

To have some indication of the speed of inflation convergence and of the output costs involved, we have simulated the case of a reduction in the inflation targets with imperfect credibility. To focus on this issue, we have used the closed economy version of the model previously presented $\left(\alpha=1, s_{c}=1\right)$. The result is a standard model. The aggregate supply curve without the backward-looking term can be written as $\pi_{t}=\beta E_{t} \pi_{t+1}+\lambda^{*} \tilde{y_{t}}$, where $\lambda^{*} \equiv \lambda\left(\gamma_{c}+\gamma_{n}\right)$. The central bank announces a reduction in the inflation rate target from $\pi^{T o}$ to $\pi^{T n}$ as of the current quarter, but private agents do not fully believe that this change is permanent. They assign a probability $b_{t}$ that at the following quarter the central bank reneges on its announcement and returns to $\pi^{T o}$. Therefore, the expected inflation rate target is given by $E_{t} \pi_{t+1}^{T}=b_{t} \pi^{T o}+\left(1-b_{t}\right) \pi^{T n}$. We have considered the case of an optimal monetary policy under discretion. ${ }^{15}$ The central bank is allowed to reoptimize every period. We have assumed that if the central bank maintains the new target, the probability of reneging on its announcement declines over time. We have used a simple law of motion: $b_{t+1}=\rho_{b} b_{t}$, where $0 \leq \rho_{b}<1 .^{16}$

Figure 7 shows the impulse responses of output gap and inflation to a reduction of 3 p.p. in the inflation target for the cases of imperfect and perfect credibility. If we compare the first announced targets to the inflation in the previous twelve months (Table 1), we verify that many countries had initial targets more than 3 p.p. lower than the previous inflation. We have assumed that the initial probability of reneging is 0.8 , and $\rho_{b}=0.8$. Since we are considering quarterly data, the latter implies that, at the end

\footnotetext{
${ }^{15}$ We have not shown the results under commitment because it is less reasonable to assume that private agents believe the central bank is committed and, at the same time, will not keep its announcement.

${ }^{16}$ The derivation is available upon request.
} 
of the year, $b_{t}=0.41$. The inflation rate refers to the four-quarter accumulated inflation above the new target. We assume that the inflation was stable at the old target before the announcement. At the end of the first year, in the case of imperfect credibility, the inflation rate is still 1.42 p.p. above the new target, and the output gap presented a reduction of $0.49 \%$ on average. ${ }^{17}$ Therefore, even assuming a relatively rapid reduction in the degree of imperfect credibility, the inflation rate converges only gradually to the new target. In the case of perfect credibility, inflation expectations converge automatically to the new target. As a result, inflation also converges quickly to the new target. It is not necessary any output gap reduction.

\section{Figure 7}

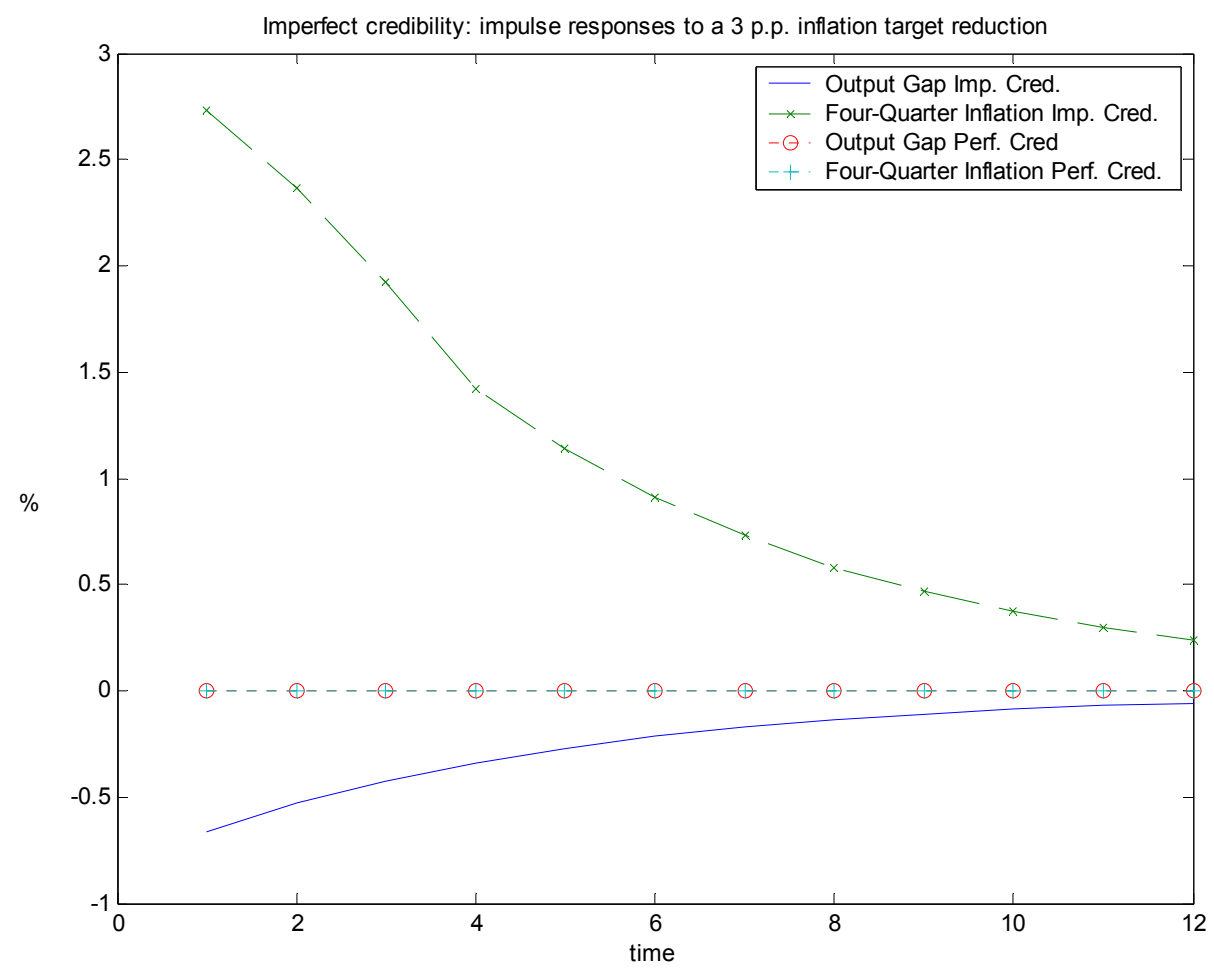

\footnotetext{
${ }^{17}$ In this simulation, we are assuming that the relative output weight in the objective function is equal to 0.3. If we increase it to 1.0, the effect is significant on the output response but low on the inflation path: the inflation rate is 1.45 , and the output gap has a reduction of $0.15 \%$ on average.
} 
Similar reasoning is applied when the economy is hit by an inflationary shock. The possibility that the central bank will not be tough for enough time increases inflation expectations, requiring a higher output reduction. The result is a higher volatility of inflation, output, and interest rate.

As stressed by Svensson (2002), the economy incurs higher output variability at the beginning of the regime to gain credibility, but later on it benefits from an improved trade-off with lower output and inflation variability, and the central bank can then be a more flexible inflation targeter.

In the Brazilian case, the construction of credibility has been a process that combines reactions to inflationary pressures and increased transparency to the public. The Central Bank has reacted to inflation expectations in a way that is consistent with the inflation targeting framework. Minella, Freitas, Goldfajn, and Muinhos $(2003)^{18}$ have estimated a reaction function for the Central Bank of Brasil for the first three and half years of inflation targeting. It relates the interest rate to deviations of the 12-month ahead expected inflation from the target, allowing also for some interest-rate smoothing and reaction to the output gap. ${ }^{19}$ Table 4 shows the estimations using inflation forecast of the central bank and of private agents (from survey). The point estimates of the coefficient on inflation expectations are greater than one and significantly different from zero in all specifications. Moreover, in most of specifications, the coefficient is statistically greater than one. ${ }^{20}$ Therefore, we can conclude that the Central Bank

\footnotetext{
18 That paper is an updated and shorter version of Minella, Freitas, Goldfajn, and Muinhos (2002).

${ }^{19}$ They have estimated the equation $i_{t}=\alpha_{1} i_{t-1}+\left(1-\alpha_{1}\right)\left(\alpha_{0}+\alpha_{2}\left(E_{t} \pi_{t+j}-\pi_{t+j}^{*}\right)+\alpha_{3} y_{t-1}\right)$, where $\mathrm{i}_{\mathrm{t}}$ is the Selic rate decided by the Monetary Policy Committee (Copom), $E_{t} \pi_{t+j}$ is inflation expectations and $\pi^{*}{ }_{t+\mathrm{j}}$ is the inflation target, both referring to 12 months ahead, and $\mathrm{y}_{\mathrm{t}}$ is the output gap.

${ }^{20}$ The point estimates, however, vary across specifications. Using private agents' expectations (sample 2000:1-2002:12), the point estimates are around 2.1-2.3, whereas with central bank expectations (sample 1999:6-2002:12) they are 3.5 and 5.7. The p-values for the test that the coefficient is equal to 1 are 0.150 , $0.101,0.012$ and 0.040 in specifications I, II, III and IV.
} 
conducts monetary policy on a forward-looking basis, and responds to inflationary pressures.

Table 4

Estimation of Reaction Function of the Central Bank of Brazil Dependent Variable: Target for the Nominal Selic Interest Rate (monthly data)

\begin{tabular}{|c|c|c|c|c|}
\hline \multirow[t]{2}{*}{ Regressors } & \multicolumn{2}{|c|}{$\begin{array}{l}\text { Using Central Bank Inflation } \\
\text { Expectations } \\
(1999: 7-2002: 12)\end{array}$} & \multicolumn{2}{|c|}{$\begin{array}{l}\text { Using Market Inflation } \\
\text { Expectations } \\
(2000: 1-2002: 12)\end{array}$} \\
\hline & I & II & III & IV \\
\hline Constant & $\begin{array}{r}1.65 \\
(1.08)\end{array}$ & $\begin{array}{l}3.06^{*} \\
(1.59)\end{array}$ & $\begin{array}{r}4.58^{* * * *} \\
(1.52)\end{array}$ & $\begin{array}{r}5.38^{* *} \\
(2.07)\end{array}$ \\
\hline Interest Rate (t-1) & $\begin{array}{r}0.90 * * * \\
(0.06)\end{array}$ & $\begin{array}{r}0.82 * * * \\
(0.09)\end{array}$ & $\begin{array}{r}0.71 * * * \\
(0.09)\end{array}$ & $\begin{array}{r}0.67 * * * \\
(0.12)\end{array}$ \\
\hline Inflation Expectations (deviations from the target) & $\begin{array}{l}5.70 * \\
(3.20)\end{array}$ & $\begin{array}{r}3.54 * * \\
(1.51)\end{array}$ & $\begin{array}{r}2.32 * * * \\
(0.53)\end{array}$ & $\begin{array}{r}2.09 * * * \\
(0.53)\end{array}$ \\
\hline Output Gap (t-1) & & $\begin{array}{r}-0.36^{*} \\
(0.21)\end{array}$ & & $\begin{array}{l}-0.10 \\
(0.15)\end{array}$ \\
\hline R-squared & 0.9129 & 0.9160 & 0.9205 & 0.9214 \\
\hline Adjusted R-squared & 0.9084 & 0.9094 & 0.9157 & 0.9140 \\
\hline \multicolumn{5}{|l|}{ LM Test for Autocorrelation of Residuals (p-values) } \\
\hline 1 lag & 0.7853 & 0.7210 & 0.6586 & 0.6411 \\
\hline 4 lags & 0.6831 & 0.5298 & 0.5362 & 0.3991 \\
\hline
\end{tabular}

Notes: Standard error in parentheses. *, ** and $* * *$ indicate the coefficient is significant at the $10 \%, 5 \%$, and $1 \%$ level, respectively. Source: Minella, Freitas, Goldfajn, and Muinhos (2003).

We also simulate the case of reduction in the inflation targets in the presence of a backward-looking component in the aggregate supply curve equal to 0.4 (therefore, $\left.\gamma_{f}=0.6\right)$. We use the open economy version of the model. The central bank reacts according to a simple expectational rule: $i_{t}=1.5 E_{t} \pi_{t+1}$. The optimal coefficients found using two different weights on the output gap in the objective function, $w_{y}=0.3$ and 
$w_{y}=1.0$, are 1.79 and 1.34 , respectively. ${ }^{21}$ As in the case of imperfect credibility, inflation decreases slowly to the new target, and the optimal output gap is negative. With a 3 p.p. reduction in the inflation target, inflation is 0.78 p.p. above the target at the fourth quarter, and the output gap reduction is $0.55 \%$ on average in the first year. In the case of a purely forward-looking aggregate supply curve, inflation converges automatically to the new target.

As the inflation targeting regime is supposed to affect inflation expectations, we can consider the possibility that the backward-looking component in the price adjustment becomes less important as credibility increases. The share of backwardlooking firms could become smaller and/or firms could consider less the past inflation to adjust prices. This would reduce the degree of persistence in inflation. Minella, Freitas, Goldfajn, and Muinhos (2003) have estimated a simple aggregate supply curve for the low inflation period in Brazil to assess if the inflation-targeting regime was accompanied by some structural change. ${ }^{22}$ They regress inflation rate on its own lags, the unemployment rate (lagged one period), and the exchange rate change in 12 months (lagged one period).

Table 5 records the results when including only one lag for inflation and when including two. The regression also includes dummy variables that multiply the constant and lagged inflation for the inflation-targeting period, ${ }^{23}$ and a dummy that assumes the value of 1 for the last three months of 2002. Without adding this last dummy, the residuals in both specifications present serial correlation. Actually, the end of 2002 is a very peculiar period, which it is difficult to be fitted by a simple Phillips curve. The

${ }^{21}$ Cecchetti and Ehrmann (1999) have found a value between 0.32 and 0.41 for inflation targeting countries. Batini, Harrison, and Millard (2001) have used 1.0 (including also a term for interest rate in the objective function).

${ }^{22}$ The procedure is similar to that in Kuttner and Posen (1999).

${ }^{23}$ Dummies for the inflation targeting period that multiply unemployment and the exchange rate do not enter significantly; therefore, they were excluded from the estimation. 
authors find that the backward-looking term has decreased. The point estimate of the autoregressive coefficient decreases from 0.56 to 0.10 in the inflation targeting period when compared to the previous period of low inflation (specification I). ${ }^{24}$

Table 5

Estimation of Aggregate Supply Curve

Dependent Variable: Monthly Inflation Rate - 1995:08 - 2002:12

\begin{tabular}{|c|c|c|}
\hline Regressors & I & II \\
\hline Constant & $\begin{array}{l}0.65^{*} \\
(0.36)\end{array}$ & $\begin{array}{l}0.70^{*} \\
(0.36)\end{array}$ \\
\hline Dummy constant ${ }^{1}$ & $\begin{array}{l}0.34 * * * \\
(0.12)\end{array}$ & $\begin{array}{l}0.51 * * * \\
\quad(0.14)\end{array}$ \\
\hline Inflation rate(t-1) & $\begin{array}{l}0.56 * * * \\
(0.11)\end{array}$ & $\begin{array}{l}0.62 * * * \\
(0.15)\end{array}$ \\
\hline Inflation rate(t-2) & & $\begin{array}{l}-0.09 \\
(0.14)\end{array}$ \\
\hline Dummy inflation rate $(\mathrm{t}-1)^{1}$ & $\begin{array}{l}-0.46^{* * *} \\
(0.17)\end{array}$ & $\begin{array}{c}-0.43 * * \\
(0.19)\end{array}$ \\
\hline Dummy inflation rate $(\mathrm{t}-2)^{1}$ & & $\begin{array}{l}-0.35^{*} \\
(0.20)\end{array}$ \\
\hline Unemployment (t-1) & $\begin{array}{l}-0.08 \\
(0.05)\end{array}$ & $\begin{array}{l}-0.09 * \\
(0.05)\end{array}$ \\
\hline Exchange rate change ( $\mathrm{t}-1)$ (twelve-month average) & $\begin{array}{l}0.08 * \\
(0.04)\end{array}$ & $\begin{array}{c}0.09 * * \\
(0.04)\end{array}$ \\
\hline Dummy $2002 Q 4^{2}$ & $\begin{array}{c}1.42 * * * \\
(0.26)\end{array}$ & $\begin{array}{c}1.47 * * * \\
(0.25)\end{array}$ \\
\hline R-squared & 0.5593 & 0.6022 \\
\hline Adjusted R-squared & 0.5271 & 0.5624 \\
\hline $\begin{array}{l}\text { LM Test for Autocorrelation of Residuals ( } p \text {-values) } \\
1 \text { lag }\end{array}$ & 0.6646 & 0.7022 \\
\hline 4 lags & 0.2218 & 0.3599 \\
\hline
\end{tabular}

Notes: Standard error in parentheses. *,** and *** indicate the coefficient is significant at the $10 \%, 5 \%$, and $1 \%$ level, respectively. Since exchange rate change refers to the 12-month change, the sample starts in 1995:07 to avoid the inclusion of data of the period before the stabilization.

1Dummy has value one in the inflation-targeting period (1999:06-2002:12), and zero otherwise. It multiplies the associated variable.

2 Dummy has value one in 2002:10 - 2002:12, and zero otherwise.

Source: Minella, Freitas, Goldfajn, and Muinhos (2003).

${ }^{24}$ This result is in line with the findings in Kuttner and Posen (2001). Using a broad dataset of 191 


\subsection{Dominance issues: fiscal, financial, and external}

We deal here with three elements that seem to be potential features of EMEs: weak fiscal regimes, the risks associated with poorly regulated financial systems, and large external shocks. Each of these problems can be seen to lead to a form of dominance: fiscal, financial or external. In the case of fiscal and financial dominance, the problems that arise on the monetary policy front are quite similar: the fear that one or both regimes will break down increases the probability that the government will inflate in the future, and, therefore, increases expected inflation. This in turn adds a great deal to the challenge of establishing a solid monetary anchor. The external dominance refers to the vulnerability to external shocks, which results in higher macroeconomic volatility.

\subsubsection{Fiscal dominance}

The success of inflation targeting or of any monetary regime requires the absence of fiscal dominance. Therefore, implementation of inflation targeting needs to be accompanied by a strong fiscal regime. But even with that, in the case of past weaknesses, it takes time for government to gain the full confidence of private agents. This fear of fiscal dominance affects inflation expectations, requiring a tighter monetary policy, which in turn negatively affects the fiscal balance.

The challenge, therefore, is to build fiscal and monetary regimes that reinforce one another. The evidence we have thus far on this issue is promising, but it may be too early to celebrate. Schaechter, Stone, and Zelmer (2000) show that the fiscal imbalance at the time inflation targeting was adopted was lower in developing countries.

monetary frameworks from 41 countries, they have found that inflation targeting reduces inflation persistence. 


\subsubsection{Financial dominance}

A problem for the conduct of monetary policy can arise when there is fear that a tightening may lead to a financial crisis. This may come as consequence of a weak and/or over-leveraged financial system, and may bring about the expectation that monetary policy will not be conducted with the goal of defending the nominal anchor of the economy. This problem can be characterized as a form of dominance, which we can name "financial dominance". For example, Goldfajn and Gupta (1999) have found that, in the aftermath of currency crises, an economy that faces a banking crises: i) has a lower probability of choosing a tight policy, and ii) when tight monetary policy is adopted, the probability of a successful recovery is lower. ${ }^{25}$

Banking sector weaknesses, and financial vulnerabilities in general, played a key role in the Asian crisis of 1997 . This type of fragility may also be an issue when the financial system exhibits a significant presence of government-owned banks, either because these banks may themselves be weak, or because the government may use its banks in an unwise manner.

Just as in the case of fiscal dominance it is necessary to work towards a strong fiscal regime, in the case of financial dominance care must be taken to make sure the regulation and supervision of the financial system is sound and permanent.

Another issue is the predominance of short-term financial contracts and lower financial depth in EMEs, which tend to weaken the monetary policy transmission mechanisms. ${ }^{26}$ According to Schaechter, Stone, and Zelmer (2000), the ratio of liquid liabilities to GDP was on average $51.0 \%$ in EMEs, and $72.0 \%$ in developed countries in 1997. The ratio of private credit to GDP was $63.9 \%$ and $81.0 \%$, respectively. Moreover,

\footnotetext{
${ }^{25}$ They have used a data set of currency crises in 80 countries for the period 1980-1998.

${ }^{26}$ Actually, there are two opposite effects in the case of short-term contracts: the wealth effect of change in interest rates is lower, but changes in the interest rates affect the cost of outstanding debt more quickly.
} 
as Taylor (2000) stresses, without longer-term markets, short-term interest rates will have to move more quickly. Therefore, we tend to observe higher interest rate volatility.

\subsubsection{External dominance: "sudden stops"}

Another possible explanation for the volatility shown in section 2 is the existence of larger shocks in EMEs. External shocks tend to play a more important role in EMEs than in developed countries. EMEs are subject to "sudden stops" in capital inflows. These shocks significantly affect the exchange rate, and consequently the inflation rate, leading to higher interest rates to curb the inflationary pressures. As a result, these economies tend to present a higher volatility of interest rates and exchange rates.

Of course, sudden stops themselves may reflect weaker fundamentals, which map into lower credit ratings, among other problems. On the other hand, the presence of large and frequent external shocks generates greater instability in the economy, and may jeopardize the fulfillment of the targets, which may in turn negatively affect the credibility of the regime. This may be seen as a form of "external dominance". It must be addressed through the strengthening of the fundamentals of the economy such as, in the case of inflation targeting, a fairly-clean exchange rate float (by that we mean the absence of an exchange-rate target) and, in general, a sufficient degree of openness and flexibility.

The data presented in Table 2 confirm the higher volatility of the interest rate in EMEs. For the exchange rate, the data is less clear, but points to a higher volatility. The coefficient of variation (the ratio of standard deviation to the average) is 0.15 in EMEs and 0.11 in developed economies. However, there are some differences within the group of developing economies. Brazil, Chile, Hungary, Peru, and South Africa presented 
significantly greater exchange rate volatility. The average of the coefficient of variation of the five countries is 0.22 .

In order to try to measure the importance of external shocks, we have run VAR estimations for selected countries. We have used monthly and quarterly data of four variables: industrial production (or GDP), consumer price index, interest rate, and exchange rate. We have used a Cholesky decomposition with the order mentioned. We have considered two specifications: i) all variables in log level, and ii) price and exchange rate in first log-difference. We have estimated for three periods: a large period (which varies across countries, but that in general starts in the 1980s), the period before the adoption of inflation targeting, and the inflation-targeting period (all of them end in mid-2002). Table 6 records the values for the variance error decomposition of interest rate and price level (or inflation rate), considering a 12-month or 4-quarter horizon, for the inflation-targeting period. In particular, we show the percentage of the forecast error of interest rate and prices (or inflation) that is explained by shocks to exchange rate. In the Brazilian and South African cases, shocks to exchange rate explain a significant part of the forecast error of interest rate and prices. In Brazil, they explain $49 \%$ of the interest rate forecast errors, and $18 \%$ of the price forecast error (this figure is not statistically significant though). South Korea has similar results using monthly data, mainly for interest rate. On the other hand, for the developed economies and for Mexico, the estimations indicate that the exchange rate does not play an important role. 
Table 6

Variance Error Decomposition After Adoption of Inflation Targeting (12-month or 4-quarter horizon) - \%

VAR with Four Variables: Industrial Production (or GDP), CPI, Interest Rate, and Exchange Rate

Estimation in levels for price and exchange rate

Shocks to exchange Shocks to exchange rate explaining forecast rate explaining forecast error for interest rate
Estimation in first difference for price and exchange rate

Shocks to exchange rate explaining forecast error for interest rate
Shocks to exchange rate explaining forecast error for inflation

Monthly Data**

Developed Economies

Canada

Sweden

UK

$\begin{array}{ll}1 & 0 \\ 2 & 8\end{array}$

0
8
17

1
4
10

1

Emerging Market Economies

Brazil

Mexico

South Africa

South Korea

$\begin{array}{cc}49^{\star} & 18 \\ 2 & 1 \\ 36^{\star} & 25^{\star} \\ 26^{*} & 7\end{array}$

8
0
$36^{*}$
32

$29 *$

1
$25^{*}$
7

Quarterly Data***

Developed Economies

Australia

Canada

New Zealand

Sweden

UK

12
0
11
4
0

Emerging Market Economies

Brazil

Mexico

South Korea

$57^{*} \quad 35$

1

* indicates that the value is significant at the $5 \%$ level.

** New Zealand and Australia do not have cpi and industrial production on a monthly basis.

*** The sample for South Africa is too short.

Exchange-rate fluctuations do not always reflect the pressure of the external shocks because of policy responses, which include interest-rate changes and direct intervention in the exchange-rate market. Some emerging markets opt not to allow the exchange rate to reflect the extent of the external shocks. Some of the arguments are related to "fear of floating" (Calvo and Reinhart, 2002). ${ }^{27}$ In addition to inflationary pressures, significant exchange rate fluctuations have other implications for the economy, such as uncertainty concerning prices and the value of dollar-denominated liabilities and assets. Huge depreciations of the domestic currency may affect the

${ }^{27}$ Reinhart and Rogoff (2002) have developed a system of reclassifying historical exchange rate regimes. They have found that regimes that were officially classified as floating in reality use a form of de facto peg. 
financial solvency of firms and financial institutions. In this case, the central bank may have additional goals in its objective function. According to Amato and Gerlach (2002), there are several reasons that may make appropriate for EMEs to give importance to the exchange rate beyond that related to its inflationary effects: i) with less developed foreign exchange markets, large shocks or capital flows cause significant volatility in the exchange rate if neglected by policies; ii) in economies with a poor history of monetary stability, the exchange rate tends to be a focal point for inflationary expectations; iii) exchange-rate fluctuations may have large impact on the relative profitability of firms across sectors; and iv) foreign currency borrowing may be significant.

Therefore, it is worth examining the spread over Treasuries of the foreigncurrency denominated debt of the country, as another indicator of external shocks. Table 7 shows the average and volatility of the spread of the Emerging Market Bond Index Plus (EMBI+) over the U.S. treasury for Brazil, Colombia, Mexico, Peru, Poland and South Korea. Except for Poland, the standard deviation is always higher than 118 basis points. In the Brazilian case, it reaches 377 basis points in the inflation targeting period.

As a result of these external pressures, we tend to observe a higher volatility of output, interest rates, and the exchange rate, and the possibility of non-fulfillment of targets tends to be higher. In the Brazilian case, the significant depreciation of the domestic currency was the main factor behind the non-fulfillment of the inflation targets in 2001 and 2002. The nominal exchange rate in Brazil accumulated an increase of 84.7\% during 2001 and 2002 (a depreciation of the domestic currency of 45.9\%), representing a real depreciation of $44.6 \%$. 
Table 7

$\mathrm{EMBI}+$ (based on monthly average)

\begin{tabular}{|c|c|c|c|c|c|c|}
\hline \multirow[b]{2}{*}{ Country } & \multicolumn{3}{|c|}{$1997: 01-2002: 12^{*}$} & \multicolumn{3}{|c|}{ After IT adoption until 2002:12** } \\
\hline & average & $\begin{array}{l}\text { standard } \\
\text { deviation }\end{array}$ & $\begin{array}{l}\text { coefficient of } \\
\text { variation } \\
\text { (s.d./average) }\end{array}$ & average & $\begin{array}{l}\text { standard } \\
\text { deviation }\end{array}$ & $\begin{array}{c}\text { coefficient of } \\
\text { variation } \\
\text { (s.d./average) }\end{array}$ \\
\hline Brazil & 879.35 & 389.07 & 0.44 & 987.14 & 377.82 & 0.38 \\
\hline Colombia & 651.18 & 118.48 & 0.18 & 648.04 & 123.83 & 0.19 \\
\hline Mexico & 443.40 & 150.03 & 0.34 & 408.37 & 130.19 & 0.32 \\
\hline Peru & 601.75 & 120.64 & 0.20 & 601.75 & 120.64 & 0.20 \\
\hline Poland & 233.03 & 38.17 & 0.16 & 232.65 & 35.88 & 0.15 \\
\hline South Korea & 236.37 & 145.39 & 0.62 & 236.37 & 145.39 & 0.62 \\
\hline
\end{tabular}

* Colombia: 1999:05 - 2002:12. Peru: 1998:01 - 2002:12. Poland: 1998:01 - 2002:12. South Korea: 1998:05 - 2002:12. For Brazil and Mexico, the data for 1997 refers to EMBI.

** South Korea: 1998:05 - 2002:12.

We use the model to simulate the effects of a shock to the real exchange rate of $45 \%$, but instead of using the UIP condition, we use an autoregressive process for the real exchange rate (with an autoregressive coefficient equal to 0.5). As before, the central bank reacts according to a simple expectational rule: $i_{t}=1.5 E_{t} \pi_{t+1}$, and the coefficient on lagged inflation is 0.4 .

Figure 8 shows the impulse responses. At the end of the fourth quarter, the fourquarter accumulated inflation reaches $5.16 \%$, and the output gap reduction is on average $6.80 \%$ in the first year. Therefore, even with a significant output gap reduction, any existent inflation target would be breached. If we consider the inflation target for Brasil in 2002 of $4 \%$, then, with this simulation, the inflation rate would reach $9.7 \%$, distant even from the upper bound of $6.5 \%$. 
Figure 8

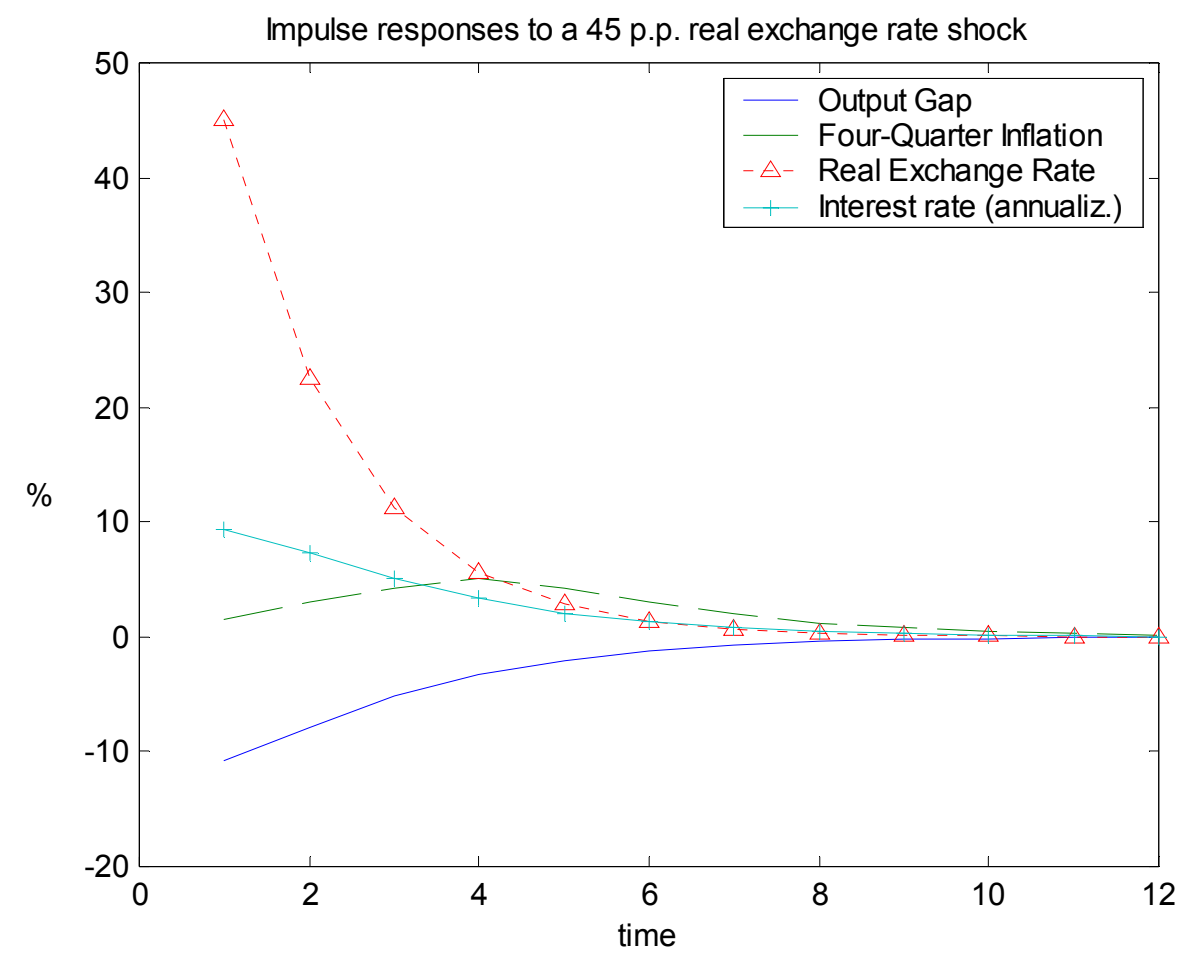

The existence of this possibility of breaching the targets due to large shocks leads us to analyze very important issues in the design of inflation targeting in emerging markets. The next section explores how to deal with higher volatility in an inflation targeting regime.

\section{How to deal with higher volatility?}

The central element of the inflation-targeting regime is the public announcement of a numerical target for inflation. However, as Mishkin (2000) stresses, inflation targeting comprises much more than that. It also involves: i) an institutional commitment to price stability as the primary goal of monetary policy, to which other goals are subordinated; ii) use of many variables for the instrument policy decision; iii) 
increased transparency of monetary policy strategy; and iv) an increased accountability of the central bank.

The issues presented in the last section imply important challenges for monetary policy. The key aspect is how to build credibility in the conduct of monetary policy and in the inflation targeting regime itself, and at the same time to be flexible enough to avoid unnecessary output costs that could lead to a perception that the regime is too costly. Communication and transparency become crucial.

One of the most appealing features of inflation targeting is the flexibility it allows monetary policy when confronted with shocks. For instance, in dealing with a supply shock, the professional consensus among academic economists and central bankers is that a central bank should accommodate the direct price-level impact of the shock while calibrating monetary policy so as to avoid further rounds of price increases. In practice, however, this may come at a cost. The central bank's commitment to low inflation may be questioned if the nature of the shock and the appropriateness of the policy response are not clear to most observers. The solution to this conundrum is to provide enough information to the public so as to make clear that the policy response is the right answer to a problem that is well understood.

In general, the optimal response will depend on the nature of the shock, on a number of economic parameters and elasticities, and on the preferences of society relative to the inflation versus output-gap volatility trade-off. At a very basic level, it is therefore crucial that the central bank make an effort to identify the size and nature of shocks, focusing in particular on whether one is dealing with supply or demand shocks, temporary or permanent shocks, and their size and inflationary impact. Once the shocks are identified, the central bank can chose a monetary policy response that will deliver the chosen feasible pair of inflation and output gap paths. 
Inflation-targeting central banks have developed a number of tools to deal with these issues. They involve the inflation targeting design, transparency, "adjusted" targets, and change in the IMF conditionality.

\subsection{Target bands, horizons and persistence of shocks}

The possibility that large shocks may cause target breaches leads to an important feature in the design of the inflation targeting regime: the size of the band around the central point of the target. Tighter bands tend to signal a preference for lower inflation volatility relative to lower output volatility. The band is typically seen as a barrier not to be broken.

However, in a world of perfect information, where all shocks are precisely identified, there is no role for bands around the inflation target. Deviations from the point target would occur as an optimal response to shocks, given the parameters of the economy and the inflation aversion of society. An optimal response to a very large shock may demand large deviations from the central point of the target, sometimes beyond the upper bound of the target. The same holds for the horizon over which inflation is allowed to deviate from the target when the economy is hit by shocks. This horizon should also be determined according to the type, size and persistence of the shock as well as the parameters mentioned above.

So why do countries opt to include target bands? While some countries may actually treat the band limit as a strict barrier not to be broken, in our view the bands should be treated mainly as a communications device. The bands should be considered mainly as checkpoints, with the central bank explaining clearly the reasons for the nonfulfillment of the targets. This discussion, however, is not easily mapped into operational guidelines that can be implemented by the central bank. As a result, it is 
necessary that the assumptions underlying the decision-making process of the central bank be clearly communicated. This means being explicit about a fairly precise path of inflation on the way back to the targeted level, so as not to loose the confidence of economic agents. Transparency therefore plays the key role of imposing enough discipline on the central bank in order to avoid the temptations depicted in the timeconsistency literature. $^{28}$

In practice, the size of the bands varies across countries: 1 percentage point in Australia and Israel, 3 percentage points in South Africa, 3.5 in Iceland, and 4 in Brazil for 2002, and 5 for 2003 and 2004. What should be the size of the bands? One possibility would be for the size of the bands to be large enough to allow that in most of the circumstances the inflation rate is within them if monetary policy is conducted efficiently. Given some variability of shocks in the economy, inflation should be inside the bands in most of the cases, say $90 \%$ of the cases. Using the model, and assuming some variance for the shocks, we obtain the standard deviation of inflation (given some optimal rule). If we assume that the random shocks are normally distributed, we would find a band size corresponding to 1.65 standard deviations of inflation.

The recurrent presence of larger shocks may also recommend higher central targets. As shown in Figure 6, the difference between the targets of EMEs and developed countries has decreased, but it is still positive. In 2002, the central point target for EMEs was 3.7\%, whereas for developed countries was $2.2 \%$. The higher target reflects not only higher past inflation but also the greater vulnerability to external shocks. One possible reason is the asymmetric effects of supply shocks. Given greater downward price rigidity, deflationary shocks tend to have a lower effect in inflation

\footnotetext{
${ }^{28}$ It seems these days that the important lesson of the time consistency literature has reached most central banks. In fact, one finds a substantial number of central bankers around the world who seem to act as inflation-averse Rogoff (1985) central bankers.
} 
than inflationary shocks. As a consequence, with higher shocks, this bias tends to be higher.

The issue of the magnitude of the response to shocks leads us also to the discussion of the horizon to be used in the inflation targeting framework. As emphasized by Svensson (2002), in practice, the "flexible inflation targeting", where some weight is given to output stabilization, means aiming to achieve the inflation target at a somewhat longer horizon. Since EMEs are more subject to larger shocks, we would consider that their target horizon should naturally be longer. A danger here, of course, is that if the central bank is still building credibility, longer horizons could be interpreted as lenience, affecting its reputation.

In practice, there is no magic number for the horizon that central banks should use to guide its reaction to supply shocks. It should be long enough to allow the workings of the monetary policy transmission mechanisms and some degree of smoothing of the effects of the shock. On the other hand, it should be short enough to neutralize part of its inflationary effect and allow convergence of inflation expectations to the target. At any rate, it is crucial that the central bank's response be clearly explained so as to avoid reputational risk. Section 5.3 presents the procedure adopted by the Central Bank of Brazil in dealing with a series of large shocks during the years 2001 and 2002.

\subsection{Monetary policy committees, meeting minutes, and inflation report}

To stress the importance of the existence of a monetary policy committee (MPC) may sound unnecessary to most observers in the more advanced economies, but it is no trivial matter in the EMEs. Until one such committee was created in Brazil, for example, monetary policy decisions were taken on an ad-hoc basis, typically at the end 
of a Board meeting, at the end of the day, when everyone was already quite exhausted, and often without the benefit of proper preparation and analysis. An MPC which meets regularly on a monthly basis has created a proper environment for what, after all, is the key role of a central bank: to run monetary policy. The MPC meetings have become a ritual that provides those responsible for setting policy with a good decision-making environment. It moves Board members away from their otherwise hectic day-to-day schedules of meetings and phone calls, and allows them to focus on the task at hand.

A crucial aspect of inflation targeting is the ability to enhance the credibility of the policy-making process and, as a result, to achieve the desired results with minimum costs. The timely publication of detailed minutes of MPC meetings is a key ingredient for an effective communications strategy. In emerging economies, where credibility is typically lower than one would like, the benefits of doing so can be substantial.

In addition to monthly-meeting minutes, most inflation targeting central banks also publish a quarterly Inflation Report where their views on economic prospects and, in particular, on inflation trends are presented in detail. ${ }^{29}$ Again, for EMEs these reports play a key role, serving the purpose of minimizing uncertainty about what the central bank is seeing, and what it is trying to achieve. The inflation reports are the appropriate vehicle for the central bank to present its views on complex issues such as the degree of exchange-rate pass-through, the degree of inflationary persistence, the workings of the transmission mechanism, and so on.

\subsection{Shocks and "adjusted" targets}

The recent experience of Brazil with inflation targeting during turbulent times serves to illustrate the practical application of the general guidelines and principles

\footnotetext{
${ }^{29}$ For an assessment of inflation reports by inflation-targeting central banks, see Fracasso, Genberg, and Wyplosz (2003).
} 
discussed above. This section summarizes the methodology that is currently being used in Brazil. It calculates the inflationary impact of current supply shocks as well as the secondary impact of past shocks (due to inertia in the inflation process). The idea is simply to accommodate the direct impact of current shocks and to choose a horizon to weed out the secondary impact of past shocks.

When facing shocks, the Central Bank of Brazil (BCB) initially considers the nature and persistence of the shock. Then it builds different inflation and output trajectories associated with different interest rate paths. Based on its aversion to inflation variability, it chooses the optimal path for output and inflation. Banco Central do Brasil (2003) has published this path and also the outcome of different paths. This is in line with Svensson's (2002) recommendations. ${ }^{30}$

However, if shocks are large and/or persistent, their inflationary effects may last one year or more. The optimal inflation path may imply a 12-month ahead inflation superior to the previous annual target. Therefore, in this situation, given that the $\mathrm{BCB}$ would not be targeting the previous inflation target, it uses an "adjusted target". More specifically, the target is adjusted in order to take into account primary effects of change in relative prices and of past inertia that will be accommodated. The new target is publicly announced. Although there is a credibility loss stemming from the target change itself, the gains in terms of transparency and communication are more significant. Private agents know the target the BCB is pursuing. Actually, keeping the old target would affect the credibility of the BCB because it could be considered unattainable. In the concept of adjusted target, the primary effect of the shock to regulated-price inflation, and the inflation inertia inherited from the previous year to be accommodated in the current year, are added to the target previously set by the

\footnotetext{
${ }^{30}$ Svensson's (2002) recommendations also involve publishing the corresponding instrument-rate plan.
} 
government. Facing cost shocks, such as the increase of regulated prices above the inflation of the other prices of the economy, monetary policy should be calibrated so as to accommodate the direct impact of shocks on the price level, but to fight their secondary effects. Furthermore, since the Central Bank also takes into account output costs, the inertial impacts of the previous year's inflation should not necessarily be fought completely.

Indeed, significant shocks, such as increases in the price of regulated utilities and the exchange rate, have been one of the main challenges faced by the BCB. Since the implementation of the Real Plan, in July 1994, for a variety of reasons, regulatedprice inflation has been well above the market prices inflation. Considering since the start of the inflation targeting period, the ratio of regulated prices to market prices rose $31.4 \%$ (1999:7 - 2003:2). As long as there is some downward rigidity in prices, changes in relative prices are usually translated into higher inflation. If these increases are treated as a supply shock, monetary policy should be oriented towards eliminating only their secondary impact on inflation, while preserving the initial realignment of relative prices. Therefore, the efforts of the BCB to quantify the first-order inflationary impact of the regulated-price inflation have become particularly important, since it helps to implement monetary policy in a flexible manner and without losing sight of the larger objective of achieving the inflation targets.

The first-order inflationary impact of the shock to regulated items is defined as the variation in regulated prices exceeding the target for the inflation rate, weighted by the share of regulated prices in the IPCA (consumer price index) and excluding the effects of the inflation inertia from the previous year and of variations in the exchange rate:

$$
\operatorname{Sh} A=\left(\pi_{a d m}-\pi^{*}\right) * \omega_{a d m}-(I A+C a A)
$$


where $\operatorname{Sh} A=$ first-order inflationary impact of regulated prices;

$\pi_{a d m}=$ inflation of regulated prices;

$\pi^{*}=$ target for the inflation;

$\omega_{a d m}=$ weight of regulated prices in the IPCA;

$I A=$ effect of the inertia in the previous year on the evolution of regulated prices;

$\mathrm{CaA}=$ effect of the exchange rate variation on the evolution of regulated prices.

The effect of the inflation inertia is excluded because inflation propagation mechanisms should be neutralized by the monetary policy over a period deemed to be appropriate (again, based on the inflation aversion and other parameters). The exchange-rate variation is excluded because this variable is affected by monetary policy and could reflect demand shocks. If the effect of exchange rate changes were automatically included, monetary policy would be validating any inflationary pressure coming from exchange rate (including demand pressures). Therefore, in defining the shock to regulated prices, only the component of relative price change that is predetermined or backward-looking, and therefore cannot be affected by monetary policy in the short run, is preserved as a first-order supply shock.

Table 8 shows how this methodology was applied to the Brazilian case for the inflation in 2003 and $2004 .{ }^{31}$ The target established by the government for 2003 is $4 \%$. However, the regulated-price shocks are estimated in $1.7 \%$. This value represents the expected contribution for the overall inflation of a change in relative prices that is not related to the inflation inertia from previous year and to the exchange rate change. Since

\footnotetext{
${ }^{31}$ See Banco Central do Brasil (2003). For a more detailed explanation of the methodology, see Freitas, Minella, and Riella (2002).
} 
these first-round effects should not be neutralized, they are added to the target of the Central Bank, leading to an adjusted target of $5.7 \%$.

Table 8

Adjusted targets for 2003 and 2004

\begin{tabular}{cccc}
\hline & Itemization & 2003 & 2004 \\
\hline (a) & Target for inflation set by the government $^{1}$ & 4.0 & 3.75 \\
(b) & Regulated-price shocks $^{1}$ & 1.7 & 1.1 \\
(c) & Inertia not to be fought in the current year $^{2}$ & 2.8 & 0.6 \\
& $\quad$ Inherited inertia from the previous year (total) & 4.2 & 1.0 \\
& $\quad$ of regulated prices & 1.4 & 0.4 \\
& $\quad$ of market prices & 2.8 & 0.6 \\
(d) & Adjusted targets (=(a)+(b)+(c)) & 8.5 & 5.5 \\
\hline
\end{tabular}

1) For the calculation of the shock, the effect of inertia and exchange rate on regulated-price inflation is deducted.

2) The inertia not to be fought in the current year corresponds to $2 / 3$ of the inertia inherited from the previous year. Source: Banco Central do Brasil (2003).

Furthermore, the Central Bank of Brazil also takes into account the nature and persistence of the shocks and the output costs involved in the disinflationary process (the output weight in the objective function is greater than zero). In this case, the Central Bank decided to fight against $1 / 3$ of the inertia inherited from previous year. This inertia is estimated in $4.2 \%$. Therefore, we have to add $2.8 \%$ to the target, leading to an adjusted target of $8.5 \%$, which was publicly announced.

The decision to pursue an inflation trajectory based upon these adjusted targets considers that monetary policy will be able to lead inflation to converge to the target tolerance interval in two years. We should stress, however, that two years is no magic number. It depends on the size and type of the shock. Figure 9 draws the actual and expected path for inflation (Banco Central do Brasil, 2003). The trajectory is compatible with the (end-of-year) adjusted targets. 
Figure 9

12-Month Inflation

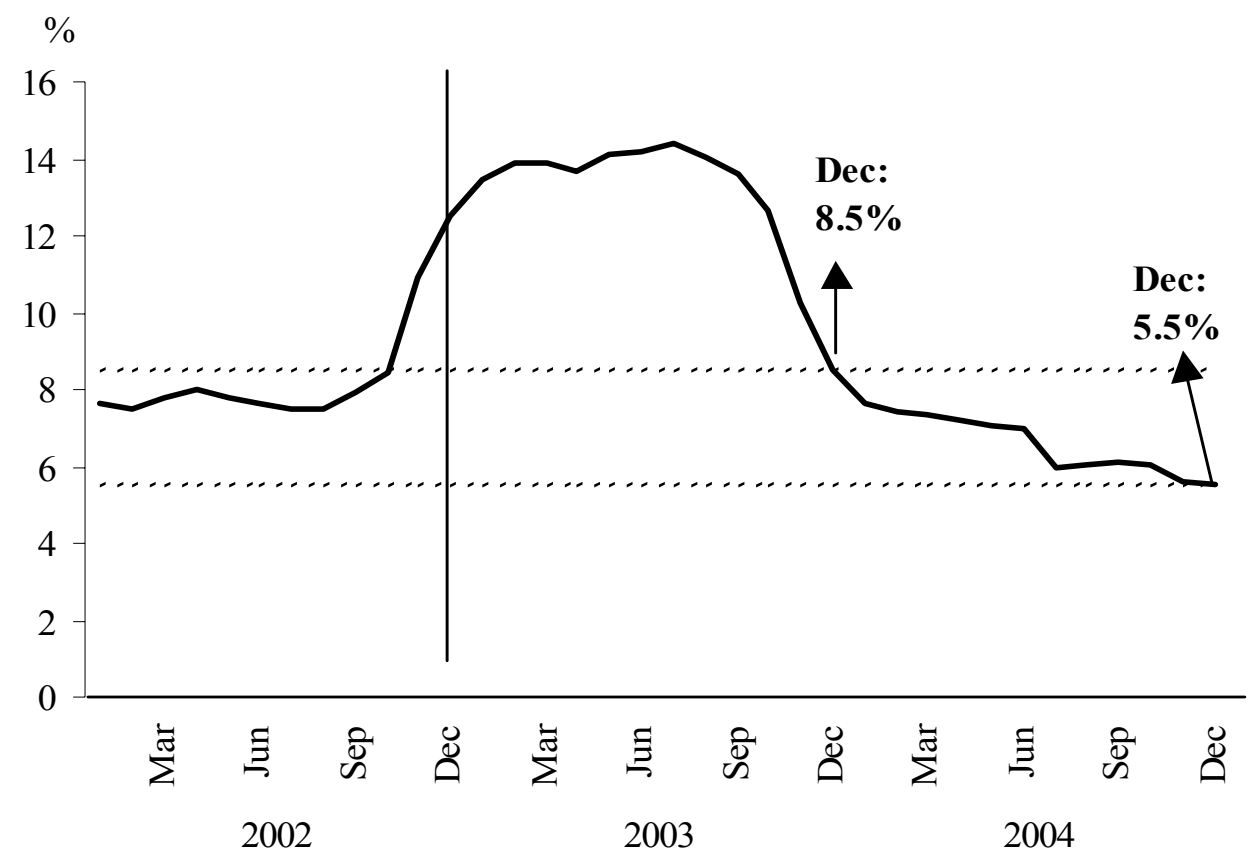

Other trajectories with steeper decreases of inflation imply an excessive loss of output. Simulations indicate that a trajectory of inflation that reaches $6.5 \%$ in 2003 , the ceiling of the target tolerance interval, would imply a $1.6 \%$ drop in GDP. Moreover, a trajectory that reaches the center of the target, $4 \%$, in 2003 , would imply an even larger decline in GDP (-7.3\%).

One could argue that the decision to neutralize the shock in a longer time horizon, based on an evaluation of the size and persistence of the shock, may lead to time consistency issues: too much accommodation in the short run leading to a loss of credibility in the long run. In fact, it is essential that the whole procedure be explained publicly in a very detailed manner, so that the agents could judge effectively whether the size and persistence of the shock justify the decision taken by the Central Bank. It is 
the transparency, therefore, that imposes enough discipline to avoid time-consistency issues.

In the inflation targeting design, a core inflation measure or the establishment of escape clauses have also been used or suggested as a way of dealing with shocks and volatilities. The main argument contrary to the use of core inflation is that it is less representative of the loss of the purchasing power of money, at a given point in time. Agents are concerned about the whole basket of consumption. In the Brazilian case, exclusion of the regulated price items would imply to leave out more than $30 \%$ of the representative consumption basket. In this sense, private agents may question a monetary policy that is not concerned about the overall consumer price index.

In general, there are two advantages in the use of the "adjusted target" procedure. First, the core inflation measure is not necessarily isolated from the effect of shocks. For example, the large depreciation shock of the Brazilian economy in 2002 led to a core inflation-calculated by the symmetric trimmed mean method-of $8.8 \%$, way above the inflation target. Second, the construction of the adjusted target is directly based on the idea that monetary policy should neutralize second-order effects of supply shocks and accommodate the first-round effects, and on the fact that some weight to output volatility should be assigned in the objective function. Therefore, the principles under which the monetary policy is conducted become more transparent.

In the case of escape clauses, the circumstances under which the central bank can justify the non-fulfillment of the targets are set in advance. It has more similarities with the adjusted target procedure than with the use of core as it does not exclude items from the inflation target, but defines circumstances in which the breach of targets can be justified. The main advantages of the adjusted target procedure are the following: i) it is 
a forward looking procedure, ii) it defines clearly the new target to be pursued by the central bank, and iii) it explains how the new target is measured.

\subsection{IMF programs and conditionality}

This section focuses on the IMF conditionality in the case of a country under inflation targeting regime. ${ }^{32}$ We stress two issues: i) the diminished role of net domestic assets (NDA) conditionality; ii) how to insert inflation performance as criterion for the assessment of monetary policy stance.

\subsubsection{NDA conditionality versus inflation targeting}

Brazil was the first country under an inflation targeting system to have an agreement with the IMF. From a theoretical point of view, the NDA conditionality, which is usually the one found in the agreements to evaluate the stance of monetary policy, is not adequate for an inflation targeting regime because it harms transparency and can force the central bank to take unnecessary monetary policy actions.

Money demand is unstable, and the monetary aggregates seem to be poor predictors of inflation. Therefore, autonomous increases in the level of money demand would require, in the case of NDA ceilings or monetary base targeting, an increase in the interest rate without any inflation targeting policy purpose. We would then observe higher volatility in the interest rate than needed. Furthermore, the imposition of a NDA ceiling can harm transparency in the sense that it would add to the inflation target another monetary policy goal. One of the main advantages of an inflation targeting regime is the definition of a clear target for monetary policy. The existence of another target affects the credibility of the main goal of monetary policy.

\footnotetext{
${ }^{32}$ See also Blejer, Leone, Rabanal, and Schwartz (2001), and Bogdanski, Freitas, Goldfajn, and Tombini (2001).
} 


\subsubsection{Inflation performance as criterion for the assessment of monetary policy stance}

In the place of NDA targets, inflation performance emerges as a natural criterion for the assessment of monetary policy stance. Of course, since inflation targets focus on inflation forecasts, assessing inflation outcomes has to take into account the shocks that hit the economy. At least two questions have to be addressed in the case of an IMF program: the frequency of the assessments (reviews), and the criteria to base the targets.

IMF programs have quarterly reviews, whereas in an inflation targeting framework the inflation performance is assessed at longer horizons. The use of annualized quarterly inflation figures as targets is not recommended because they are more volatile and subject to the strong influence of temporary shocks. Brazil has used a 12-month inflation as the monetary quarterly target in the Technical Memorandum of Understanding with the IMF. It also includes inner and outer bands of 1.0 p.p. and 2.5 p.p., respectively, both above and below the central targets. Figure 10 shows the targets agreed with the IMF in the second review of Brazil's performance in March 2003. The target for the 12-month inflation of the quarter following the agreement considers the inflation verified in the three previous quarters plus an estimate for the next quarter inflation. However, if an important shock hits the economy in the next quarter, inflation may breach the target.

The path of the targets with the IMF should be consistent with the annual targets of the inflation targeting regime. This is in line with the forward-looking or preemptive nature of the inflation targeting system. At the same time, it eliminates the problem of the effect of quarterly figures because the time horizon for the inflation target could be defined as four quarters. Eventual (predicted) pick-ups of inflation during the year 
should not alter the monetary policy committee decisions, provided inflation is expected to converge to the target; and shocks in one year keep affecting inflation in the following year, but only through the direct channel, that is, via the autoregressive component of inflation.

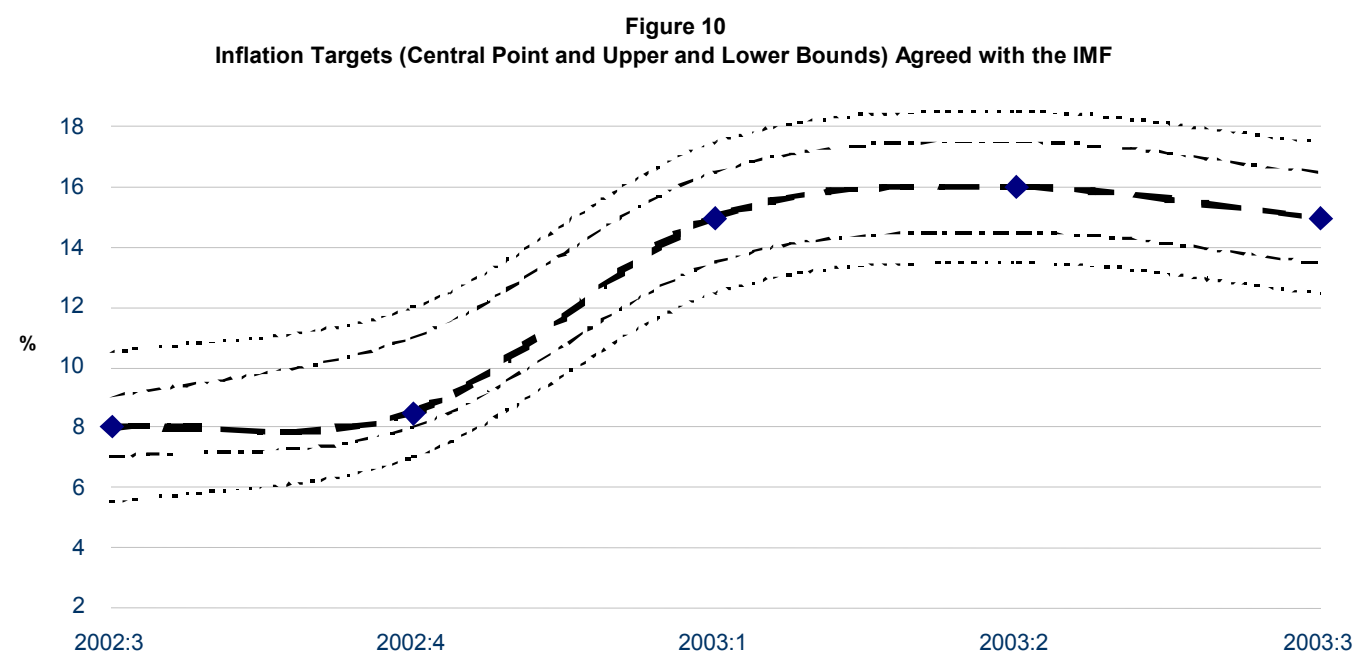

The main difficult arises with the necessity of agreement between the IMF and the central bank concerning the model used and the associated risks, which also may be time consuming. Therefore, it also involves the construction of credibility by the forecast-making process of the central bank.

In the agreements of Brazil with the IMF, the inflation forecasts made by the Central Bank have been used as an important criterion for the definition of the targets. However, the revisions are still made on a quarterly basis based on the actual inflation. The reasons for the non-fulfillment of targets have been explained thoroughly to the public and to the IMF. 


\section{Conclusions}

Inflation targeting in EMEs has been relatively successful but has proven to be a challenging task. The volatility of output, inflation, interest rate and exchange rate has been higher than in developed countries. Several issues have led these economies to face this less favorable trade-off. The process of building credibility, the necessity of reducing inflation levels, the dominance issues, and the larger shocks have played an important role.

To deal with this more volatile environment, we recommend i) high levels of communication and transparency; ii) target bands treated mainly as communication devices; iii) a methodology to calculate the convergence path following a shock (adjusted targets); and iv) better IMF conditionality under inflation targeting.

\section{References}

Amato, Jeffery D., and Stefan Gerlach (2002), "Inflation Targeting in Emerging Market and Transition Economies: Lessons after a Decade", European Economic Review, 46: 781-790.

Ball, Laurence, and Niamh Sheridan (2003), "Does Inflation Targeting Matter?", NBER Working Paper no. 9577, Mar.

Banco Central do Brasil (2003), "Open-Letter sent by Banco Central do Brasil's Governor, Henrique de C. Meirelles, to the Minister of Finance, Antonio Palocci Filho", available at www.bcb.gov.br

Batini, Nicoletta, Richard Harrison, and Stephen P. Millard (2001), "Monetary Policy Rules for an Open Economy", Bank of England, Working Paper. 
Bernanke, Ben S., Thomas Laubach, Frederic S. Mishkin, and Adam S. Posen (1999), Inflation Targeting: Lessons from the International Experience, Princeton, Princeton University Press.

Blejer, Mario I., Alfredo M. Leone, Pau Rabanal, and Gerd Schwartz (2001), "Inflation Targeting in the Context of IMF-Supported Adjustment Programs", IMF Working Paper no. 01/31, Mar.

Bogdanski, Joel, Paulo S. de Freitas, Ilan Goldfajn, and Alexandre A. Tombini (2001), "Inflation Targeting in Brazil: Shocks, Backward-Looking Prices, and IMF Conditionality", Working Paper Series no. 24, Central Bank of Brazil, Aug.

Calvo, Guillermo, and Carmen Reinhart (2002), "Fear of Floating”, Quarterly Journal of Economics, 117(2): 379-408, May.

Cecchetti, Stephen G. and Michael Ehrmann (1999), "Does Inflation Targeting Increase Output Volatility? An International Comparison of Policymakers' Preferences and Outcomes", NBER, Working Paper no. 7426.

Corbo, Vittorio, and Klaus Schmidt-Hebbel (2001), "Inflation Targeting in Latin America", Central Bank of Chile, Working Paper no.105, Sept.

Corbo, Vittorio, Óscar Landerretche, and Klaus Schmidt-Hebbel (2002), "Does Inflation Targeting Make a Difference?", In: Loayza, Norman, and Raimundo Soto (eds.), Inflation Targeting: Design, Performance, Challenges, Santiago, Chile, Central Bank of Chile, pp.221-269.

Dennis, Richard (2002), "Solving for Optimal Simple Rules in Rational Expectations Models", Federal Reserve Bank of San Francisco, Working Paper, Sept.

Fracasso, Andrea, Hans Genberg, and Charles Wyplosz (2003), "How Do Central Banks Write? An Evaluation of Inflation Reports by Inflation-Targeting Central Banks”, Geneva Reports on the World Economy Special Report 2, May. 
Freitas, Paulo S. de, André Minella, and Gil Riella (2002), "Metodologia de Cálculo da Inércia Inflacionária e dos Efeitos dos Choques dos Preços Administrados", Notas Técnicas do Banco Central do Brasil no. 22, July. (English translation in Banco Central do Brasil (2002), Inflation Report, 4(2):123-128, June).

Fuhrer, Jeffrey (1997), "The (Un)Importance of Forward-Looking Behavior in Price Specifications", Journal of Money, Credit, and Banking, 29(3): 338-350.

Fuhrer, Jeffrey, and Georger Moore (1995), "Inflation Persistence", Quarterly Journal of Economics, 110(1): 127-159.

Galí, Jordi and Mark Gertler (1999), "Inflation Dynamics: A Structural Econometric Analysis", Journal of Monetary Economics, 44: 195-222.

Galí, Jordi, and Tommaso Monacelli (2002), "Monetary Policy and Exchange Rate Volatility in a Small Open Economy", NBER, Working Paper no. 8905.

Goldfajn, Ilan, and Poonam Gupta (1999), "Does Monetary Policy Stabilize the Exchange Rate Following a Currency Crisis?", IMF Working Paper no. 42, Mar.

Kuttner, Kenneth N., and Adam S. Posen (1999), "Does Talk Matter After All? Inflation Targeting and Central Bank Behavior", Federal Reserve Bank of New York Staff Report no. 88, Oct.

Kuttner, Kenneth N., and Adam S. Posen (2001), "Beyond Bipolar: A ThreeDimensional Assessment of Monetary Frameworks", International Journal of Finance and Economics, 6: 369-387.

McCallum, Bennett T., and Edward Nelson (2000), "Monetary Policy for an Open Economy: an Alternative Framework with Optimizing Agents and Sticky Prices", Oxford Review of Economic Policy, 16(4): 74-91. 
Minella, André, Paulo S. de Freitas, Ilan Goldfajn, and Marcelo K. Muinhos (2002), "Inflation Targeting in Brazil: Lessons and Challenges", Central Bank of Brazil, Working Paper Series no. 53, Nov.

Minella, André, Paulo S. de Freitas, Ilan Goldfajn, and Marcelo K. Muinhos (2003), "Inflation Targeting in Brazil: Constructing Credibility under Exchange Rate Volatility", Central Bank of Brazil, Working Paper Series no. 77, July (forthcoming in Journal of International Money and Finance).

Mishkin, Frederic (2000), "Inflation Targeting in Emerging Market Countries", American Economic Review, 90(2): 105-109.

Mishkin, Frederic, and Klaus Schmidt-Hebbel (2002), "A Decade of Inflation Targeting in the World: What Do We Know and What Do We Need to Know?", In: Loayza, Norman, and Raimundo Soto (eds.), Inflation Targeting: Design, Performance, Challenges, Santiago, Chile, Central Bank of Chile, pp.171-219.

Reinhart, Carmen M. and Kenneth S. Rogoff (2002), "The Modern History of Exchange Rate Arrangements: A Reinterpretation", NBER, Working Paper no. 8963.

Roberts, John M. (1997), "Is Inflation Sticky?", Journal of Monetary Economics, 39: 173-196.

Roberts, John M. (1998), "Inflation Expectations and the Transmission of Monetary Policy", Mimeo, Board of Governors of the Federal Reserve System, Oct.

Rogoff, Kenneth (1985), "The Optimal Degree of Commitment to an Intermediate Monetary Target", Quarterly Journal of Economics, 100(4):1169-1189.

Rotemberg, Julio J., and Michael Woodford (1998), "Interest-Rate Rules in an Estimated Sticky Price Model", NBER, Working Paper no. 6618. 
Schaechter, Andrea, Mark P. Stone, and Mark Zelmer (2000), "Adopting Inflation Targeting: Practical Issues for Emerging Market Countries", International Monetary Fund, Occasional Paper no. 202.

Schmidt-Hebel, Klaus, and Alejandro Werner (2002), "Inflation Targeting in Brazil, Chile, and Mexico: Performance, Credibility and the Exchange Rate", Working Paper no. 171, Central Bank of Chile, July.

Svensson, Lars E.O. (2000), "Open-Economy Inflation Targeting", Journal of International Economics, 50: 155-183.

Svensson, Lars E.O. (2002), "Monetary Policy and Real Stabilization", mimeo, Sept.

Taylor, John B. (2000), "Using Monetary Policy Rules in Emerging Market Economies", Stanford University, mimeo, Dec.

Truman, Edwin M. (2002), "Inflation Targeting and the International Financial System", mimeo, Oct.

Woodford, Michael (2002), "Inflation Stabilization and Welfare", mimeo, Princeton University, Mar. 